\title{
Marine Antibody-Drug Conjugates: Design Strategies and Research Progress
}

\author{
Yu-Jie Wang ${ }^{1,2,+}$, Yu-Yan Li ${ }^{2,+}$, Xiao-Yu Liu ${ }^{1}$, Xiao-Ling $\mathrm{Lu}^{1}{ }^{1}$, Xin Cao ${ }^{3, *}$ and Bing-Hua Jiao ${ }^{1, *}$ \\ 1 Department of Biochemistry and Molecular Biology, Second Military Medical University, Shanghai 200433, \\ China; wyjcherish@163.com (Y.-J.W.); biolxy@163.com (X.-Y.L.); luxiaoling80@126.com (X.-L.L.) \\ 2 Department of Medicinal Chemistry, China Pharmaceutical University, Nanjing 210009, China; \\ yuyanli@cpu.edu.cn \\ 3 Shanghai Institute of Organic Chemistry, Chinese Academy of Sciences, Shanghai 200032, China \\ * Correspondence: caoxin@sioc.ac.cn (X.C.); bhjiao@smmu.edu.cn (B.-H.J.); \\ Tel.: +86-21-5492-5486 (X.C.); +86-21-8187-0970 (ext. 8001) (B.-H.J.) \\ + These authors contribute equally to this paper. \\ Academic Editor: Peer B. Jacobson \\ Received: 26 October 2016; Accepted: 4 January 2017; Published: 13 January 2017
}

\begin{abstract}
Antibody-drug conjugates (ADCs), constructed with monoclonal antibodies (mAbs), linkers, and natural cytotoxins, are innovative drugs developed for oncotherapy. Owing to the distinctive advantages of both chemotherapy drugs and antibody drugs, ADCs have obtained enormous success during the past several years. The development of highly specific antibodies, novel marine toxins' applications, and innovative linker technologies all accelerate the rapid R\&D of ADCs. Meanwhile, some challenges remain to be solved for future ADCs. For instance, varieties of site-specific conjugation have been proposed for solving the inhomogeneity of DARs (Drug Antibody Ratios). In this review, the usages of various natural toxins, especially marine cytotoxins, and the development strategies for ADCs in the past decade are summarized. Representative ADCs with marine cytotoxins in the pipeline are introduced and characterized with their new features, while perspective comments for future ADCs are proposed.
\end{abstract}

Keywords: marine toxins; antibody-drug conjugates; monoclonal antibody; targeted therapy

\section{Introduction}

While cancer is one of the most serious diseases threatening human life, traditional chemotherapy and common antibody tumor therapy offer low efficacy due to weak target selectivity and tumor-killing efficiency. As an innovative therapeutic choice, antibody-drug conjugates (ADCs) demonstrate distinctive advantages of both cytotoxin drugs and antibody drugs in cancer treatment. The marine cytotoxins, including auristatins and their derivatives (mainly MMAE and MMAF), take important position in ADCs payloads, and fully demonstrate their highly toxic merit under the accurate guidance of monoclonal antibodies.

As early as a century ago, German immunologist Paul Ehrlich proposed the concept of "magic bullet" which could selectively deliver cytotoxic drugs to tumor tissues by way of a targeting agent [1]. In the following decades, the evolved ADCs are well constructed with monoclonal antibody (mAb), highly cytotoxic compounds and a bioactive linker (Figure 1). The antibody efficiently carries cytotoxins to targets via specific antigen-antibody reactions, and the ADC-antigen complex is internalized by endocytosis [2]. Once internalized, the ADC moves into cancer cells and experiences further degradation to release drugs for killing tumor cells (Figure 2) [3]. Additionally, the conjugation strategy has an essential impact on the pharmacokinetics (PK) of cytotoxic drugs and can increase the half-life of these cytotoxins from hours to days [4]. 


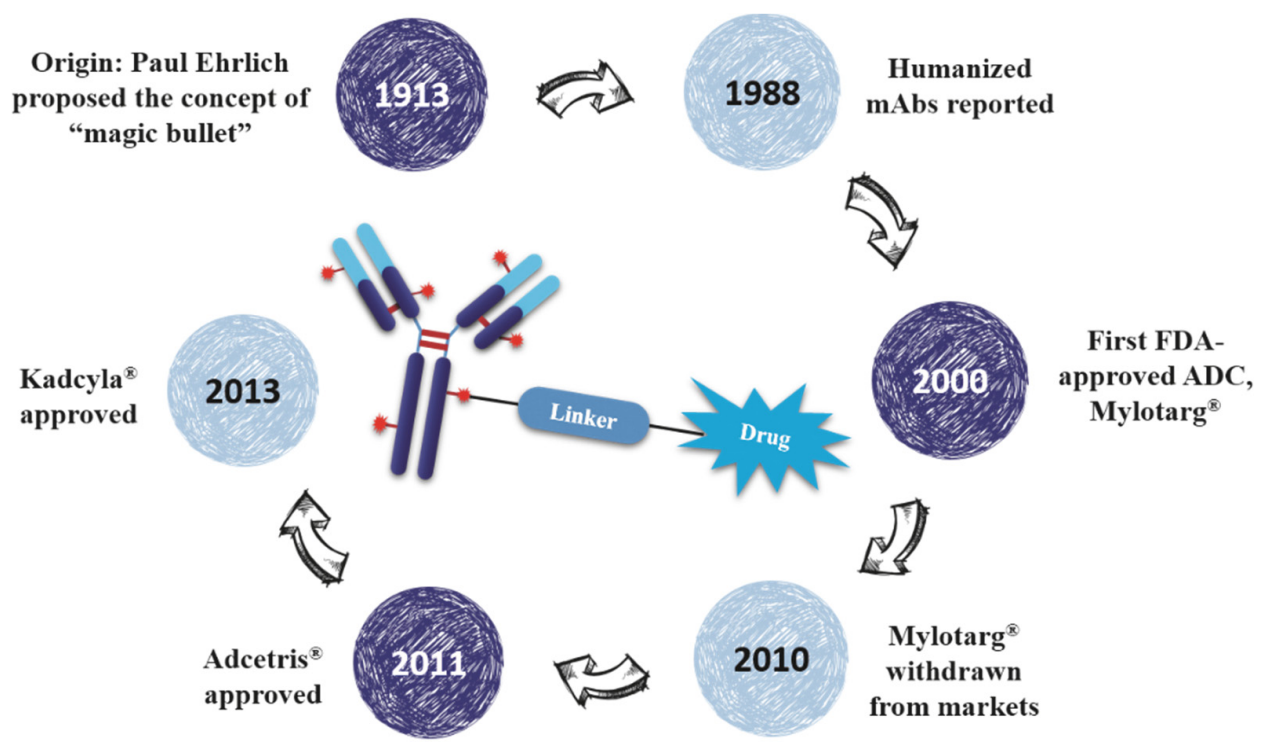

Figure 1. The brief history and schematic diagram of ADCs.

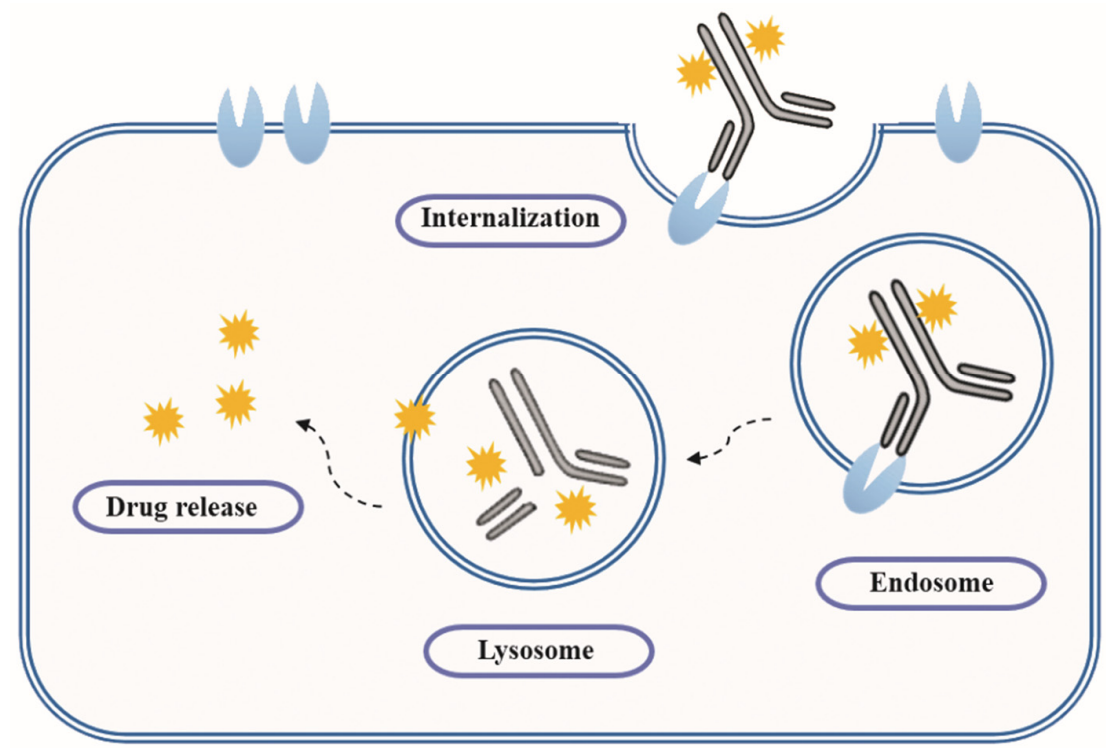

Figure 2. Action mechanism of ADCs.

Eighty-seven years after Dr. Ehrlich's proposal, the first ADC, Mylotarg ${ }^{\circledR}$ (Pfizer, gemtuzumab ozogamicin), was approved for the treatment of acute myelocytic leukemia (AML) by the US Food and Drug Administration (FDA) in 2000. Though it was withdrawn from the market in 2010 for efficacy and overall survival problems [5], increasing attention and rapid progress towards ADCs have been made by pharmaceutical industry. In 2011, Seattle Genetics launched Adcetris ${ }^{\circledR}$ (Brentuximab Vedotin), the second FDA-approved ADC for Hodgkin's lymphoma (HL) and anaplastic large-cell lymphoma (ALCL) treatments [6]. Subsequently, Roche launched the third ADC drug Kadcyla ${ }^{\circledR}$ (Trastuzumab Emtansine) towards HER2-positive breast cancers in 2013 (Figure 3) [7]. Till 2016, more than 50 ADCs' clinical trial recruitments and enrollments have started all over the world. According to the prediction of "Antibody Drug Conjugates Market" (2nd Edition, published by Research \& Markets), 10 new ADCs will come into the clinical market in the next decade, and the overall ADCs market will reach 10 billion dollars by 2024 . 


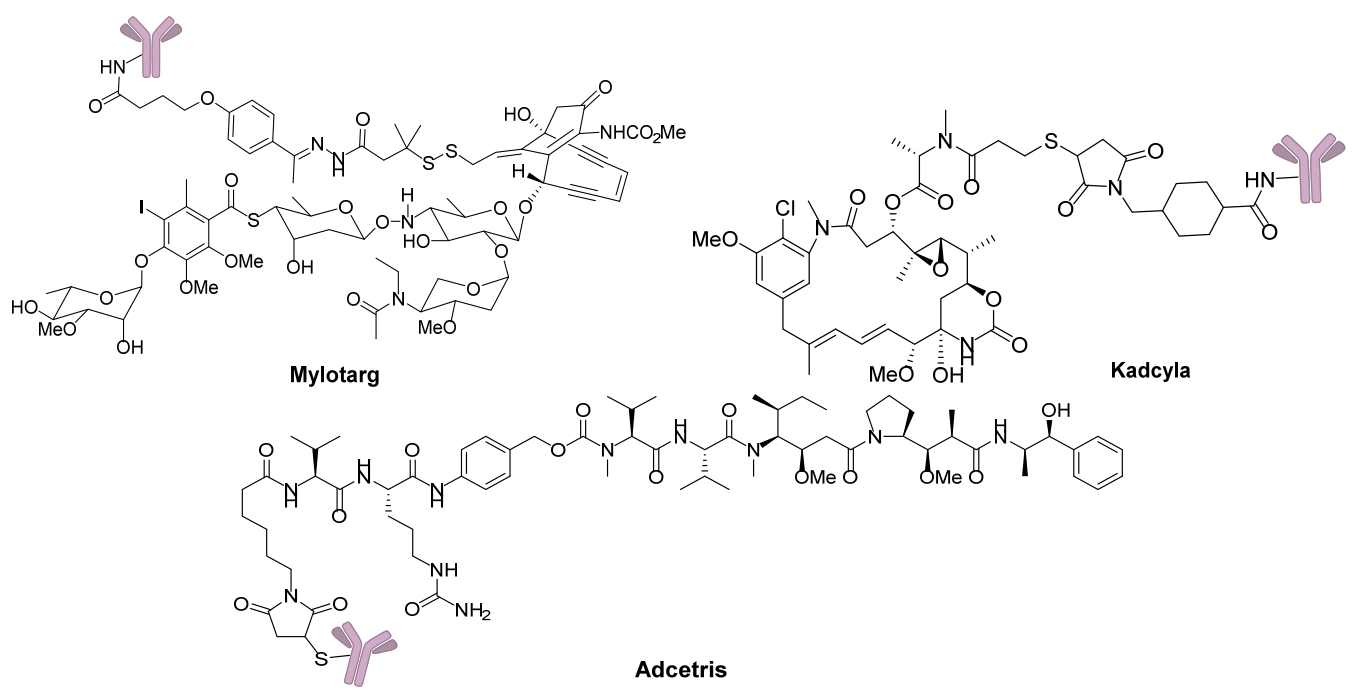

Figure 3. Three FDA-approved ADCs.

\section{ADCs in Clinical Trial}

ADCs have grown to be one of the most promising tumor therapeutic drug research fields for their targeting, high efficiency, and low toxicity merits; the opportunity to develop brand new marine ADCs is coming. At present, there are more than 50 ADCs in the pipeline which have started their clinical trial recruitments or been in different clinical trial phases all over the world as shown in Table 1. Among these ADC candidates, Inotuzumab ozogamicin, an anti-CD22 calicheamicin conjugate developed by Pfizer, has started its Phase III study in treating relapsed and refractory acute lymphoblastic leukemia (ALL), and is expected to be launched in 2017. Around 20 ADCs are going to start Phase II recruitments or are in Phase II stage, and around 30 candidates have started their Phase I clinical trials $[1,8]$. Another exciting trend for ADC drugs is that the newer drugs have a wider range of indications. While early indication of ADCs mainly focused on leukemia and lymphoma, an increasing number of ADCs are now being aimed at solid tumors such as breast and ovarian cancers. For example, Glembatumomab vedotin, which is developed by Celldex, demonstrated high efficiency in Phase II study towards locally advanced or metastatic breast cancer-with an initial focus in triple negative disease; it is also in development for the treatment of Stage III and IV melanoma. Besides, Anti-PSMA ADC, RG7599, MLN0264 are recognized as efficient prostatic cancer, ovarian cancer and gastric cancer treatment agents. 
Table 1. ADCs in clinical research

\begin{tabular}{|c|c|c|c|c|c|c|}
\hline ADCs & Phase & Target & Antibody & Linker & Payload & Indication(s) \\
\hline Inotuzumab ozogamicin & Phase III & CD22 & $\mathrm{Hz} \operatorname{IgG}_{4}$ & Hydrazone & Calicheamicin & NHL, ALL, CML \\
\hline Gemtuzumab ozogamicin & Phase II & CD33 & $\mathrm{Hz} \mathrm{IgG}_{4}$ & Hydrazone & Calicheamicin & AML, APL \\
\hline MDX-1203 & Phase I & CD70 & n.d. & Valine-citrulline & Duocarmycin & RCC, NHL \\
\hline Glembatumomab vedotin & Phase II & GPNMB & $\mathrm{Hu} \mathrm{IgG}_{2}$ & Valine-citrulline & MMAE & Breast cancer, melanoma \\
\hline Anti-PSMA ADC & Phase I/II & PSMA & $\mathrm{Hu} \mathrm{IgG}_{1}$ & Valine-citrulline & MMAE & Prostatic cancer \\
\hline RG-7593/DCDT-2980S & Phase I/II & CD22 & $\mathrm{Hz} \mathrm{IgG}_{1}$ & Valine-citrulline & MMAE & NHL, DLBCL \\
\hline RG-7596/DCDS-4501A & Phase I/II & CD79b & $\mathrm{Hz} \mathrm{IgG}_{1}$ & Valine-citrulline & MMAE & NHL, DLBCL \\
\hline RG7599/DNIB-0600A & Phase I/II & $\mathrm{NaPi} 2 \mathrm{~b}$ & $\mathrm{~Hz} \operatorname{IgG}_{1}$ & n.d. & MMAE & Ovarian cancer, NSCLC \\
\hline MLN0264 & Phase I/II & GCC & n.d. & n.d. & MMAE & Pancreatic cancer, gastric carcinoma \\
\hline ASG-22M6E & Phase I & Nectin-4 & $\mathrm{Hu} \mathrm{IgG}_{1}$ & Valine-citrulline & MMAE & Solid tumors \\
\hline ASG-5ME & Phase I & SLC44A4 & $\mathrm{Hu} \mathrm{IgG}_{2}$ & Valine-citrulline & MMAE & Pancreatic cancer, prostatic cancer \\
\hline AGS-67E & Phase I & CD37 & $\mathrm{Hu} \mathrm{IgG}$ & Valine-citrulline & MMAE & Lymphoma, AML \\
\hline BAY-79-4620 & Phase I & CA-IX & $\mathrm{Hu} \mathrm{IgG}_{1}$ & Valine-citrulline & MMAE & Solid tumors \\
\hline RG7458/DMUC-5754A & Phase I & MUC16 & $\mathrm{IgG}_{1}$ & n.d. & MMAE & Ovarian cancer, pancreatic cancer \\
\hline RG7636 & Phase I & ETBR & n.d. & n.d. & MMAE & Melanoma \\
\hline AGS-15ME & Phase I & SLITRK6 & $\mathrm{Hu} \mathrm{IgG}_{2}$ & Cleavable linker & MMAE & Urothelial neoplasms \\
\hline $\mathrm{HuMax}^{\circledR}-\mathrm{TF}$ & Phase I & $\mathrm{TF}$ & $\mathrm{Hu} \mathrm{IgG}_{1}$ & Valine-citrulline & MMAE & Solid tumors \\
\hline SGN-LIV1A & Phase I & LIV-1 & $\mathrm{Hz} \mathrm{IgG}_{1}$ & Valine-citrulline & MMAE & Breast cancer \\
\hline AGS-16C3F & Phase I/II & ENPP3 & $\mathrm{Hu} \mathrm{IgG}$ & MC & MMAF & RCC \\
\hline SGN-CD19A & Phase I/II & CD19 & $\mathrm{Hz} \mathrm{IgG}_{1}$ & MC & MMAF & Lymphoma, DLBCL \\
\hline ABT-414 & Phase I/II & EGFR & $\mathrm{Hu} \mathrm{IgG}_{1}$ & n.d. & MMAF & Solid tumors, glioma, SCC \\
\hline GSK-2857916 & Phase I & BCMA & $\mathrm{Hz} \mathrm{IgG}_{1}$ & MC & MMAF & MM \\
\hline AGS-16M8F & Phase I & ENPP3 & $\mathrm{Hu} \mathrm{IgG}_{2}$ & MC & MMAF & RCC \\
\hline A1-mc-MMAF & Phase I & $5 \mathrm{~T} 4$ & $\mathrm{~Hz} \mathrm{IgG}_{1}$ & MC & MMAF & Solid tumors \\
\hline IMGN-529 & Phase I/II & CD37 & $\mathrm{IgG}_{1}$ & Thioether & DM1 & NHL, CLL, DLBLC \\
\hline Lorvotuzumab mertansine & Phase I/II & CD56 & $\mathrm{Hz} \mathrm{IgG}_{1}$ & SPP & DM1 & SCLC, MM \\
\hline AMG-172 & Phase I & CD27L & $\mathrm{Hu} \mathrm{IgG}_{1}$ & MCC & DM1 & ccRCC \\
\hline IMGN-289 & Phase I & EGFR & $\mathrm{Hz} \operatorname{IgG}$ & SMCC & DM1 & Solid tumors \\
\hline AMG-595 & Phase I & EGFRvIII & n.d. & SMCC & DM1 & Glioma \\
\hline SAR-3419 & Phase II & CD19 & $\mathrm{Hz} \mathrm{IgG}_{1}$ & SPDB & DM4 & NHL, DLBCL \\
\hline BT-062 & Phase II & CD138 & $\mathrm{Ch} \mathrm{IgG}_{4}$ & SPDB & DM4 & MM \\
\hline BAY-94-9343 & Phase I/II & Mesotherin & $\mathrm{Hu} \mathrm{IgG}_{1}$ & SPDB & DM4 & Solid tumors \\
\hline IMGN-853 & Phase I/II & FOLR1 & $\operatorname{IgG}_{1}$ & n.d. & DM4 & Solid tumors \\
\hline SAR-566658 & Phase I & CA6 & $\mathrm{Hu} \mathrm{IgG}_{1}$ & SPDB & DM4 & Solid tumors \\
\hline IMGN-388 & Phase I & Integrin $\alpha v \beta 3$ & $\mathrm{Hu} \mathrm{IgG}_{1}$ & SPDB & DM4 & Solid tumors \\
\hline BIIB-015 & Phase I & Cripto & $\mathrm{Hz} \mathrm{IgG}_{1}$ & SPDB & DM4 & Solid tumors \\
\hline Labetuzumab-SN-38 & Phase I/II & CD66e & $\mathrm{Hz} \mathrm{IgG}_{1}$ & Phenylalanine-lysine & SN38 & CRC \\
\hline IMMU-132 & Phase I/II & TROP-2 & $\mathrm{Hz} \mathrm{IgG}_{1}$ & CL2A & SN38 & Epithelial carcinomas, solid tumors \\
\hline SGN-CD33A & Phase I/II & CD33 & $\mathrm{Hz} \operatorname{lgG}_{1}$ & Valine-alanine & PBDs & AML, APL \\
\hline SGN-CD70A & Phase I & CD70 & n.d. & Valine-alanine & PBDs & RCC, lymphoma \\
\hline SC16LD6.5 & Phase I/II & Fyn3 & SC16 & n.d. & D6.5 & SCLC \\
\hline Milatuzumab doxorubicin & Phase I/II & CD74 & $\mathrm{Hz} \mathrm{IgG}_{1}$ & Hydrazone & Doxorubicins & MM \\
\hline SYD985 & Phase I & HER2 & $\mathrm{Hz} \operatorname{IgG}$ & n.d. & n.d. & Solid tumors \\
\hline IGN523 & Phase I & CD98 & $\mathrm{Hz} \operatorname{lgG}$ & n.d. & n.d. & AML \\
\hline
\end{tabular}

n.d.: not disclosed. 


\section{ADCs Design}

ADCs structurally consist of a monoclonal antibody, a bioactive linker, and payloads. For a successful ADC, four requirements should be simultaneously met: (1) suitable target; (2) highly specific antibody; (3) ideal linker; and (4) highly efficient cytotoxic drugs. ADC research involves many interdisciplinary subjects and high-tech research fields, which include the design and preparation of recombination mAbs, linker design, optimized conjugation of cytotoxic compounds, etc. At the same time, the drug:antibody ratios (DARs), antibody homogeneity, the distribution and metabolism of mAbs, effective release of drugs, and some other problems need to be taken into account. Finally, ADCs are obtained via the integration of all these high technologies. Any tiny problem will affect the safety and efficacy of ADCs $[9,10]$.

\subsection{Antigen and Indication}

It is essential to choose a suitable target for designing a successful ADC, which is closely related with the efficacy and safety of drugs. An ideal biological target must overexpress on tumor cell membrane while only slightly express or does not express at all on normal cells [11,12]. ADCs are internalized after the antibody recognizes the antigen and cytotoxic drugs are released to kill the target cells. In the pipeline, most ADCs targets are tumor associated markers and proteins, such as EGFR, CD19, CD22, CD30, CD79a, etc. In accompany with more tumor associated markers identified, more novel antigens such as SLC44A4, PSMA, and 5T4 have been explored as new ADCs targets [1,13]. Moreover, as ADC targets, these tumor markers expressed on different kinds of tumor cells are also well recognized via biological identifications. These characterizations are extremely helpful to determine the potential hematologic and solid tumor indications of ADCs (Table 2).

Table 2. Carcinomas and Specific Antigens.

\begin{tabular}{cc}
\hline Indications & Antigen Targets \\
\hline NHL & CD19, CD20, CD21, CD22, CD37, CD70, CD72, CD79a/b, CD180 \\
HL & CD30 \\
AML & CD33, CD98 \\
MM & CD56, CD74, CD138, ETBR \\
Lung cancer & CD24, CD56, CD326, Cripto, FAP, Mesothelin, GD2, 5T4, NaPi2b, \\
CRC & FOLR1, Integrin $\alpha$ V33, Fyn3 \\
Pancreatic cancer & CD74, CD227, nectin-4, CA19-9, MUC-4, MUC16, alpha v beta6, GCC \\
Breast cancer & CD174, GPNMB, CRIPTO, nectin-4, LIV1A \\
Ovarian cancer & MUC16, TIM-1, Mesothelin, NaPi2b \\
Melanoma & GD2, GPNMB, ED-B, PMEL 17, ETBR \\
Prostate cancer & PSMA, STEAP-1, TENB2 \\
Renal cancer & CAIX, TIM-1, CD27L, CD70, ENPP3 \\
Mesothelioma & Mesothelin \\
Urothelial cancer & SLITRK6 \\
Glioma & EGFRvIII \\
\hline
\end{tabular}

Except for these traditional antigen targets, more and more novel targets are identified and have been applied to ADC design. CD70, a member of the neoplasm necrosis superfamily, is discovered to be highly expressed on the surface of different hematologic and solid malignancies but restricted to express in normal tissues. CD70 related ADC drug for immunological therapy was developed due to its rapid internalization when bound to the antibody [14]. SGN-CD70A, a CD70 targeted ADC, whose $\mathrm{mAb}$ is connected with pyrrolobenzodiazepines (PBDs) via a protease-sensitive linker, is in Phase I clinical trial for RCC and other lymphomas (NCT02216890). MDX-1203, developed by Medarex/BMS, takes the prodrug CC-1065 as payload and conjugates to the anti-CD70 mAb with a protease-sensitive linker [15]. Recently, MDX-1203 has completed Phase I in a multicenter, open-label, dose-escalation, multi-dose clinical study of subjects with advanced/recurrent ccRCC or relapsed/refractory B-cell NHL (NCT00944905). 
PSMA (prostate-specific membrane antigen) is a type II inherent membrane protein specifically expressing on the prostate epithelial cell membrane. PSMA is an excellent target for ADCs with high selectivity that not only expresses on $90 \%$ of prostatic cancer but also $85 \%$ of neovascularization of solid tumors. The PSMA targeted mAbs could be rapidly internalized with receptor-mediated endocytosis after combining with the antibody $[16,17]$. The named anti-PSMA ADC whose mAbs connect with cytotoxins via a stable thioether linker has already finished phase II clinical trials in patients with metastatic castration-resistant prostate cancer (mCRPC) [18,19].

GPNMB (glycoprotein nonmetastatic melanoma protein $b$ ) is a type I transmembrane glycoprotein expressed in different tissues. Studies indicate that GPNMB up-regulates or abnormally expresses in several malignancies, including melanoma, breast cancer, and gliomas [20-22]. Glembatumumab vedotin, a fully human anti-GPNMB $\operatorname{IgG}_{2}$ antibody CR011 conjugating with MMAE via a protease-sensitive linker, is in phase I/II clinical trials for various metastatic melanoma and breast cancer $[23,24]$. Moreover, GPNMB is a potential target for other malignant neoplasms, including hepatocellular carcinoma and glioblastoma. Recently, phase II trial studies have shown its great potential in treating patients with osteosarcoma (NCT02487979).

Trophoblast glycoprotein (TPBG), also known as 5T4, is a carcinoembryonic antigen and a therapeutic target for several clinical anticancer drugs. Usually TPBG only expresses during embryonic development period while no expressions are detected in normal tissues [25]. However, the high expressions of 5T4 are detected from severe solid tumors, including ovarian, colorectal, and lung cancers [26-28]. A1-mc-MMAF, a humanized anti-5T4 $\operatorname{IgG}_{1}$ antibody conjugating to MMAF with a maleimidocaproyl linker, displays specific targeting efficacy for lung and breast cancer transplantation tumors; it is currently in clinical trial phase I [29].

\subsection{Monoclonal Antibody}

\subsubsection{Antibody Structure}

The antibody is a glycoprotein belonging to the immunoprotein superfamily that can recognize the specific antigen. An antibody is constructed with two heavy chains and two light chains, which can be divided into constant regions and variable regions. The topological structure of the antibody can be seen as letter " $Y$ ", while its variable regions situate on the terminals of two arms that can be regarded as the antigen-binding fragment $(\mathrm{Fab})$. Moreover, a small fraction of amino acid residues changes intensively in the variable regions that decide the specificity of the antigen-antibody reaction, which is called the hyper-variable region. The glycosyl groups combine on the petiole of the "Y", which is called the crystalline fragment $(\mathrm{Fc})$.

According to different heavy chain types, antibodies could be classified as 5 isotypes, among which $\mathrm{IgG}$ is commonly used as the monoclonal antibody in clinical treatments for its long half-life character. IgG could also be split into four subtypes, $\operatorname{IgG}_{1}, \operatorname{IgG}_{2}, \operatorname{IgG}_{3}$, and $\operatorname{IgG}_{4}$, of which $\operatorname{IgG}_{1}$, IgG 2 , and $\operatorname{IgG}_{4}$ are more suitable for ADC design [30,31]. Additionally, since the monoclonal antibody has inherent anticancer properties, while IgG1 is able to generate stronger antibody-dependent cell-mediated cytotoxicity (ADCC) and complement-dependent cytotoxicity (CDC) towards cancer cells than $\operatorname{IgG}_{2}$ and $\mathrm{IgG}_{4}, \mathrm{IgG}_{1}$ is the most widely used IgG category in ADCs [32-34].

The antibody is a carrier for transporting drugs to target cells, and ADCs are mostly in the form of ADC-antigen complexes when internalizing into the cells. Some antibody-antigen complexes themselves have poor internalization character; however, their ADC conjugates can enhance their internalization process. For example, rituximab is an anti-CD20 antibody with poor internalization character, but its MMAE conjugates can improve their efficacy by optimizing the internalization of complexes [35]. 


\subsubsection{History of Therapeutic MAbs}

The antibody plays an important role for ADCs in control of targeted elimination of cancer cells. With the rapid development of gene engineering, cell engineering, and antibody engineering, the monoclonal antibody has gradually undergone transformations from early murine and chimeric $\mathrm{mAbs}$ to humanized and fully human $\mathrm{mAbs}$, from which the immunogenicity problems of the antibody are greatly reduced and their half-lives in blood are obviously prolonged. All these progress pave the way for improved efficacy of ADCs.

Three decades ago, murine mAbs were used in clinical research. However, compared with human $\mathrm{IgG}$, the murine mAbs own short half-life, weakly binding to the human neonatal $\mathrm{Fc}$ receptor (FcRn) and low ADCC and CDC effects. They also produce allergic reactions and anti-drug antibodies (ADAs). As a result, they could not reach the satisfactory level of efficacy in cancer therapy [32,36]. Subsequently, through genetic engineering projects, chimeric mAbs were developed for overcoming the inherent immunogenicity and weak effector function of murine mAbs, by transplanting entire variable regions of a mouse antibody to the constant regions of a human antibody. Compared with the murine mAbs, the half-life of chimeric mAbs were prolonged, as well as immunogenicity were also reduced, however, the ADA problems were still remained [37,38]. More recently, only after the hyper-variable regions of murine were grafted onto the human antibody, and the humanized mAbs were generated, the ADA problems were basically solved as well as the mAb properties were greatly improved [39]. With the in vitro phage display technology and transgenic mice expressed human variable regions, full human $\mathrm{mAbs}$ with humanized variables and constant regions are developed. These humanized mAbs owns little immunogenicity and are more similar characters with human endogenous IgGs [40-43]. Nowadays, humanized and fully human mAbs have been the mainstream antibody applied in ADCs (Table 3) [34,44].

Table 3. FDA-Approved Therapeutic Antibodies for Cancer.

\begin{tabular}{cccccc}
\hline Generic Name & Trade Name & Target & Antibody & Indication(s) & Year of First Approval \\
\hline Edrecolomab & Panorex & EpCAM & Murine IgG & CRC & 1995 \\
Ibritumomab tiuxetan & Zevalin & CD23 & Murine IgG & NHL & 2002 \\
${ }^{131}$ I-labeled tositumumab & Bexxar & CD20 & Murine IgG & NHL & 2003 \\
Rituximab & Rituxan & CD20 & Chimeric IgG & B-NHL & 1997 \\
${ }^{131}$ I-labeled ch-TNT & n.d. & n.d. & Chimeric IgG & Lung cancer & 2003 \\
Cetuximab & Erbitux & EGFR & Chimeric IgG & CRC & 2004 \\
Brentuximab & Adcetris & CD30 & Chimeric IgG & ALCL, HL & 2011 \\
Trastuzumab & Herceptin & HER2 & Humanized IgG & Breast cancer & 1998 \\
Gentuzumab ozogamcin & Mylotarg & CD33 & Humanized IgG & Leukemia & 2000 \\
Alemtuzumab & Campath & CD52 & Humanized IgG & B-CLL & 2001 \\
Bevacizumab & Avastin & VEGF & Humanized IgG & CRC, lung, breast cancer & 2004 \\
Nimotuzumab & TheraCIM & EGFR & Humanized IgG & Epithelial cancer & 2005 \\
Pertuzumab & Perjeta & HER2 & Humanized IgG & Breast cancer & 2012 \\
Panitumumab & Vectibix & EGFR & Human IgG & CRC & 2007 \\
Ofatumumab & Arzerra & CD20 & Human IgG & CLL & 2009 \\
Ipilimumab & Yervoy & CTLA4 & Human IgG & Melanoma & 2011 \\
\hline
\end{tabular}

The high affinity between antibody and antigen is crucial for effective target killing. Studies have shown that $\mathrm{Kd}=10 \mathrm{nM}$ is the basic requirement for antibodies, since the antibodies can effectively accumulate on tumor sites when the value of $\mathrm{Kd}$ reaches $10^{-7} \mathrm{M}$ [45]. In addition, the antibody should be stable and own a long half-life in blood, and could effectively trigger endocytosis. There are 125 antibodies which could recognize 89 specific antigens in human body; among these, 55 targeting antigens are related to anticancer diseases [34], while panitumumab and cetuximab are the tumor-targeting $\mathrm{mAbs}$ for targeting epidermal growth factor receptor (EGFR) [34,46]. Adcetris adopts the chimeric $\operatorname{IgG}_{1}$ (cAC10) that can recognize the CD30 receptor on the cells of Hodgkin's lymphoma and anaplastic large cell lymphoma [47]. 


\subsubsection{Novel MAbs}

Due to its antineoplastic activity of inherent ADCC and CDC, $\operatorname{IgG}_{1}$ is commonly used in ADCs; however, more improved IgGs have been proposed for new generation of ADCs. It has been found that the glycosylations play significant roles in the function and stability of antibodies. The interaction between lgG-Fc and receptor depends on the bilateral saccharide structures, which can affect the ADCC activity [48]. For example, Obinutuzumab (Gazyva) greatly improved its ADCC effect through glycoengineering modification, which supplies additional targeted killing towards cancer cells [49].

Novel bispecific antibodies have appeared. As specified, the binding domains of these antibodies own different functions simultaneously, for example one antibody can interact with two different types of target antigens [50]. Catumaxomab (Removab), the first bispecific mAb coming into the market in 2009, is considered as a trifunctional macromolecule, which can recognize CD3 on T cells, recognize EpCAM on other tumor cells, and facilitate ADCC for tumor cell killing [51].

Antibody fragments as ADC carriers have also making striking progress. For traditional ADC drugs, only a few candidates are found aiming at solid tumor indications. It is mainly because that the large molecular weight of the full size antibody $(\sim 150 \mathrm{kDa})$ makes it difficult to penetrate capillary endothelial cell and traverse tumor's extracellular space to interior part of solid tumor, as a result that only a small percentage of antibody can reach the targeting cells. Except for penetration and the inefficient extravasation of antibodies, "antigen barrier effect" is another problem, caused by their trapping by antigen on perivascular tumor cells $[52,53]$. To solve these problems, antibody fragments are taken into account [54]. Scientists prepared small molecular weight conjugates, such as single-chain variable fragments (scFvs, $25 \mathrm{kDa})$, antigen-binding fragment (Fab, $50 \mathrm{kDa})$, diabody ( $55 \mathrm{kDa})$, $\mathrm{SIP} /$ minibody $(80 \mathrm{kDa})$ (Figure 4$)$ with improved penetrability and increasing amount of drugs that could reach deeper tumor cells [45]. Some researches have found that the SIPs/miniantibodies exhibit the best results on the efficient tumor uptake and a suitable rapid plasma clearance when compared with other antibody fragments [55-57]. However, these smaller proteins also have their own problems with less half-life and rapid plasma clearance, so the higher binding affinity is even more important should be noted for utilizing these miniaturization antibodies, because the in vivo half-life as well as the drug efficacy will also be affected corresponding to the reduced molecular weights of these antibody fragments [58].
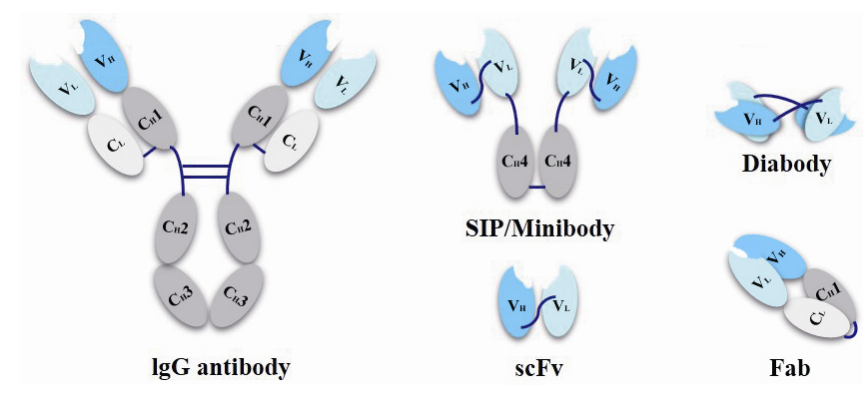

Figure 4. Schematic representation of miniaturization antibodies.

\subsection{Site of Conjugation}

\subsubsection{Non-Specific Conjugation}

The conjugation site is the binding site between the monoclonal antibody and the linker-payload. Most ADCs in the pipeline adopt the traditional "non-specific conjugation" techniques, using the lysine and cysteine as ADCs conjugation sites. Firstly, the naked $\varepsilon$-amino group of lysine on the surface of the monoclonal antibody own excellent chemical reactivity and water solubility for chemical conjugations. The lysine sites can be directly conjugated under mild condensation conditions with linkers without processing or modification. Secondly, the thiol group of cysteine on the surface of $\mathrm{mAb}$ 
is also ideal conjugation site. However, the thiol groups of cysteines always exist in a disulfide bond form, including both intra-chain and inter-chain disulfide bonds. Commonly, the thiols used to connect linkers are obtained by inter-chain disulfide bond reduction, without affecting the conformation folding of the recognition sites $[59,60]$. Compared with the lysine conjugation sites, the superiority of cysteine sites is they own much lower heterogeneity, however, the disadvantage of cysteine sites is that their reduced disulfide bonds may affect the structure stability of entire ADCs.

\subsubsection{Site-Specific Conjugation}

Usually an average of four to six toxin molecules could kill a target cell [61]. However, studies have indicated that the drug:antibody ratios (DARs) for these non-specific conjugation ADCs are probably distributed from one to eight, as a result the conjugated ADCs are a mixture of antibodies with different number of drugs. For example, the number of cytotoxic drug MMAE in Adcetris is between zero and eight with an average DAR value of 3.5 [62]. Recent researches showed a certain intracellular concentration of drugs determines the antitumor activity of ADC in vivo [63], so the higher DARs may be beneficial to deliver more drug to tumors. The inhomogeneity of the preparation of ADCs is a challenge for both drug production and quality control, and simultaneously has a great influence on in vivo distribution, metabolism, and efficacy. This would be the most important disadvantage for non-specific conjugations. In order to solve the inhomogeneity problem, scientists have proposed various site-specific conjugation strategies, for making unified ADC DARs. Commonly, the specific sequence of $\mathrm{mAbs}$ can be site-directed, modified, and introduced active functional groups as a chemical reaction site [64-66]. Extra cysteine or unnatural amino acids can be site-directed via these gene engineering methods; for example, serine and $p$-acetylphenylalanine (pAcPhe) could be used to replace cysteine through site-directed mutagenesis. Moreover, Bertozzi's team utilized the special formylglycine-generating enzyme (FGE) to recognize the CXPXR sequence, by which they could realize the substitution of the cysteine with formylglycine quantitatively and site-specifically. Consequently, the introduced orthometric active formyl groups in the $\mathrm{mAb}$ can be the specific chemical reaction site to solve the inhomogeneity of ADCs [66].

Scientists also developed many other special organic chemical strategies for optimizing and increasing the coupling selectivity. For example, PolyTherics utilizes the characteristic of moderate distance of the two sulfydryls from the reduction of the disulfide bond in antibody. A special ThioBridge ${ }^{\mathrm{TM}}$ is formed via two-ring formation of Michael addition reactions, which has higher stability and better reaction specificity compared with traditional links. The single ingredient with four MMAE as the payload of the ADC prepared by ThioBridge ${ }^{\mathrm{TM}}$ technology accounts for $78 \%$ of all components, which is much higher than traditional preparation (Figure 5) [61-68]. Analogously, Sorrento and Concortis utilize cyclization via c-Lock ${ }^{\mathrm{TM}} / \mathrm{K}-$ Lock $^{\mathrm{TM}}$ technology. This approach can obtain ADC drug almost without the use of naked antibodies, and its sulfur bridge bond is stable and has good reaction specificity. Igenica also adopts dithiopyridylmaleimide (DTM) to insert a dicarbon bridge (Figure 6).

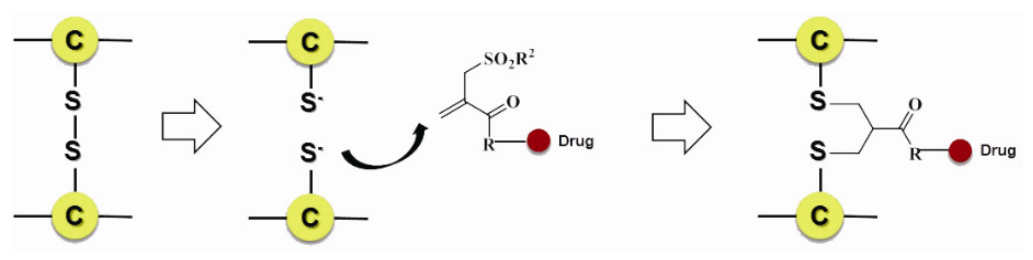

Figure 5. Schematic ThioBridge ${ }^{\mathrm{TM}}$.

SynAffix initiated and came up with GlycoConnect ${ }^{\mathrm{TM}}$ that sugar units with azide, sulfydryl or chlorine atom could be introduced into the glycosyl areas of the antibody via recombination. These functional groups can be used specifically for coupling with the effector molecules; for example, 
the acetylenic bond can react with azide via "click chemistry", and homogeneous and site-specific ADCs are obtained (Figure 7) [69].

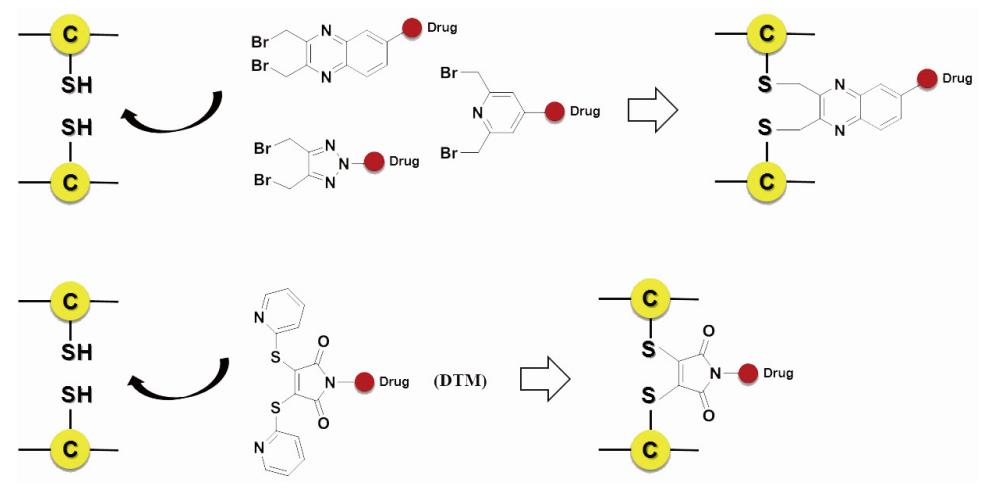

Figure 6. Schematic c-Lock ${ }^{\mathrm{TM}} / \mathrm{K}-$ Lock $^{\mathrm{TM}}$.

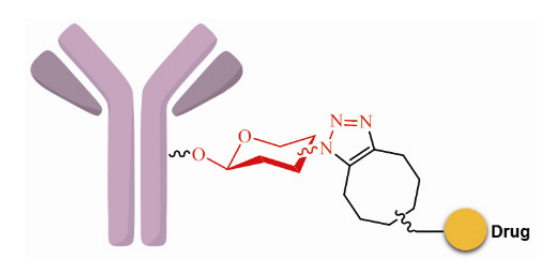

Figure 7. Schematic GlycoConnect ${ }^{\mathrm{TM}}$.

Some studies have suggested that saccharides play an important role in antibody function and pharmacokinetics. Non-natural saccharides can be integrated to the sugar chains of antibody via the metabolism to introduce novel structures with better activity or provide potential new sites for drug conjugation [70]. The non-natural saccharides connect with the linker-payload to obtain ADCs with high homogeneity via maleimide chemistry. The terminal fucose on the heavy chain N-linked saccharides of the antibody can be replaced with fucose analogs by fucosyltransferases VIII, and the saccharides with novel structures are obtained [71,72]. 6-Thiofucose peracetate is a fucose analog that offers a convenient site for conjugation (Figure 8); ADCs with this connection site have favorable activity, immunological specificity, and stability.

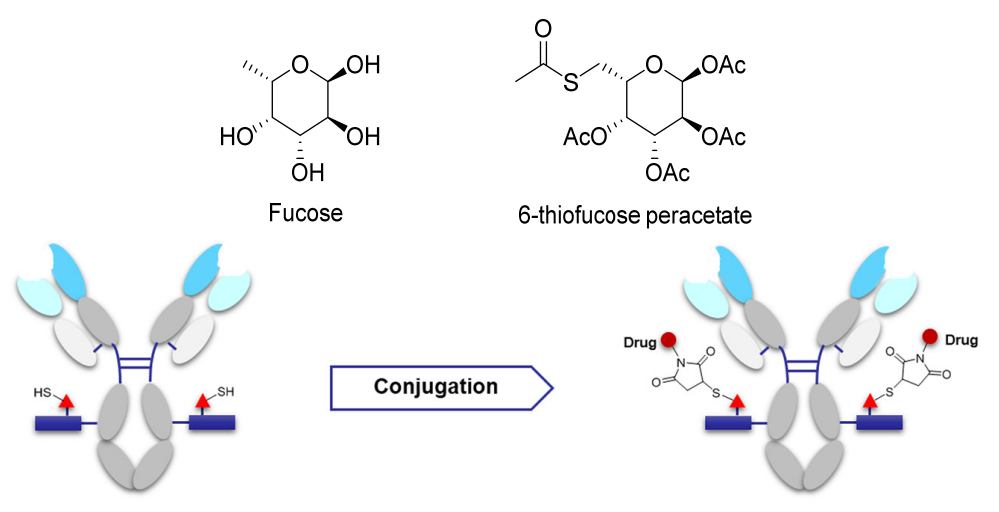

Figure 8. Schematic of antibody saccharides for conjugation and structures of fucose. Monosaccharide symbols used are as follows: triangle, fucose; rectangle, GlcNAc and mannose.

\subsection{Linker}

The linker is the bridge to connect the antibody and drugs, which can be divided into the spacer, trigger, and self-immolative part (Figure 9). However, not all linkers contain all these parts. The linker 
decides the release of drugs in the cells and has a significant effect on the entire kinetic property of the drugs, their efficacies and so on. First, an ideal linker plays the role of connector and carrier, and guarantees that the ADC is soluble and stable in the aqueous solution. Second, the linker should keep considerably stable in the blood circulation to reduce the potential toxicity and side effects brought about from the early release of the drugs [73]. The earliest launched ADC drug Mylotarg only showed a narrow therapeutic index result from the instability of the hydrazone linker in plasma. Finally, when the ADC is internalized into the cell after antibody-antigen binding, the drug should be rapidly released under the action of lysosomes or other enzymes to kill the target cells.

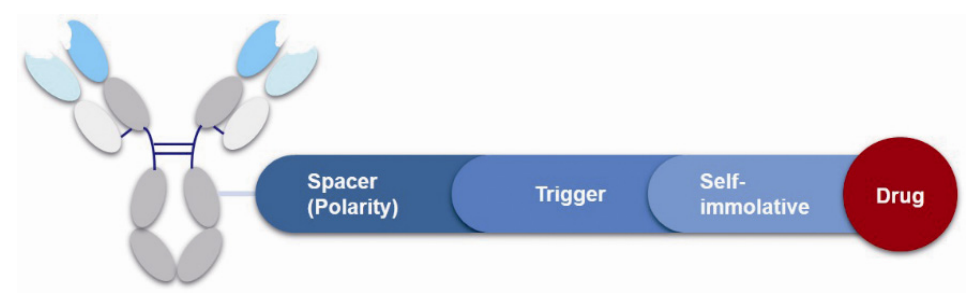

Figure 9. Structure of linker in ADCs.

\subsubsection{Spacer}

The spacer is the part of the linker that connects to the monoclonal antibody. The linker with lysine as the connection site reacts with the $\varepsilon$-amino of lysine by acylation, mainly including lipophilic SPDB disulfide without charges, maleimidomethyl cyclohexane-1-carboxylate (MCC), sulfo-SPDB with a charged polar group, and the 4-(4-acetylphenoxy)butanoic acid (AcBut) spacer in the hydrazone linker (Figure 10a) [74-76]. Mylotarg, the first launched ADC, has an AcBut spacer, while Kadcyla adopted MCC. The maleimide, which has an excellent reactivity with sulfydryl, is usually introduced to connect to the cysteine in the antibody, including maleimidocaproyl (MC) and maleimidomethyl cyclohexane-1-carboxylate (MCC). Importantly, all known ADCs with the auristatin payload adopt $\mathrm{MC}$ to connect with the antibody, because the MC can provide enough space for proteases to recognize the valine-citrulline. However, maleimide is unstable in blood and may lead to early breaking of the drug-linker. In order to achieve a better level of efficacy, some studies have indicated that adding an amino group in the adjacent position of maleimide could effectively prolong maleimide's half-life under the neutral plasma condition [77].

(a)<smiles>CCCCCSSC(C)(C)CC</smiles>
SPDB

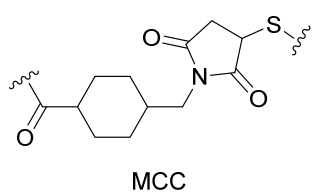<smiles>CC(=O)CCCOc1ccc(/C(C)=N/NC(=O)CC(C)(C)C)cc1</smiles>

AcBut (hydrazone)

(b)<smiles>CCCCC(CC(C)C)CC(C)C</smiles>

Figure 10. Structures of the spacer and polarity parts: (a) three representative connections of the linker to the antibody; and (b) the polarity of the linker. 
The overall polarity of ADCs also has important impact on their pharmacokinetics, efficacy, and DAR of ADC drugs. Usually, the drug loading capacity will be increased as much as possible to enhance the efficacy, however, most cytotoxins are hydrophobic, which causes aggregation and insolubilization when connecting to the antibody [78]. This limits the drugs loading to the antibody and decreases their affinity with antigens. Additionally, the hydrophobicity can generate multi-drug resistance since the P-glycolprotein will excrete these drugs out of tumor cells and cause reduced efficacy [79]. Consequently, a polarity part, such as a polyethylene glycol (PEG) or a sulfate group, can be added to the spacer to increase the overall hydrophilia and polarity of ADCs (Figure 10b) [80].

\subsubsection{Trigger}

According to different action modes, the linker can be divided into cleavable and non-cleavable linkers as shown in Table 4. Due to different working mechanisms, a more suitable connection type can be chosen based on different target environments, payloads, and indications.

Specifically, the cleavable linker mainly includes three working modes. The first category is acid-sensitive linker, which releases drugs according to the changed environmental $\mathrm{pH}$ value. With the gradually decreasing of $\mathrm{pH}$ value from extracellular $(\mathrm{pH}=7.4)$ to intracellular $(\mathrm{pH}=5-6)$ and then to the lysosome $(\mathrm{pH}=4.8)$, the acid-sensitive trigger is activated and the drugs released [81]. The hydrazone group belongs to the acid-sensitive linker, which has been applied in CMC-544 and IMMU-110. The second category is glutathione-sensitive linker, containing a disulfide bond that can be reduced by glutathione and release drugs taking the advantage of much higher intracellular glutathione concentration than that of plasma [74]. SAR3419 and IMGN901 are representative drugs of this category in the pipeline. The last category is protease-sensitive linker that recognizes and cleaves the specific peptide to release drugs by some proteases in the lysosome of tumor cells. Valine-citrulline $(\mathrm{v}-\mathrm{c})$ is the most common peptide used in current clinical research [82]. Adcetris, approved by the FDA, connects MMAE with the antibody by this linker $[83,84]$. Phenylalanine-lysine (p-l) and valine-alanine (v-a) have also been adopted in some other ADCs, such as Labetuzumab-SN-38 and SGN-CD70A. Addtionally, the $\beta$-glucuronide linker with a drug release mechanism based on $\beta$-glucuronidase is a recently developed useful linker, which indicated high efficacy at well-tolerated ADC doses [85].

A non-cleavable linker relies on the degradation of whole antibody after internalization of ADCs. The drugs are commonly released in the form of amino acid modification, while the antibody is completely hydrolyzed to amino acids in the lysosome. MCC and thioether are the most common non-cleavable linkers; for example, Kadcyla adoptes MCC to connect maytansinol with trastuzumab [75]. Bystander effects, another important consideration in ADC design, is a potential mechanism that the released payload is able to diffuse out of the cell and kill neighboring cells. Compared to cleavable linkers, non-cleavable linkers are even more stable in blood and not able to diffuse to adjacent cells. For instance, Kadcyla (T-DM1) releases lysine-DM1 with less membrane permeability instead of DM1, is not able to diffuse into neighboring cells [86].

As new effort to expand the applicability of ADCs beyond oncology, a novel pyrophosphate ester linker has been initiated to obtain the targeted delivery of glucocorticoids to immune cells (Figure 11). These phosphate linker-glucocorticoid molecules have high solubility in water, stability in blood, and a range of reactivities in the lysosome environment, and all these superior characters lead to wide applications in ADCs fields [87]. 
Table 4. Representative Triggers in Linkers.

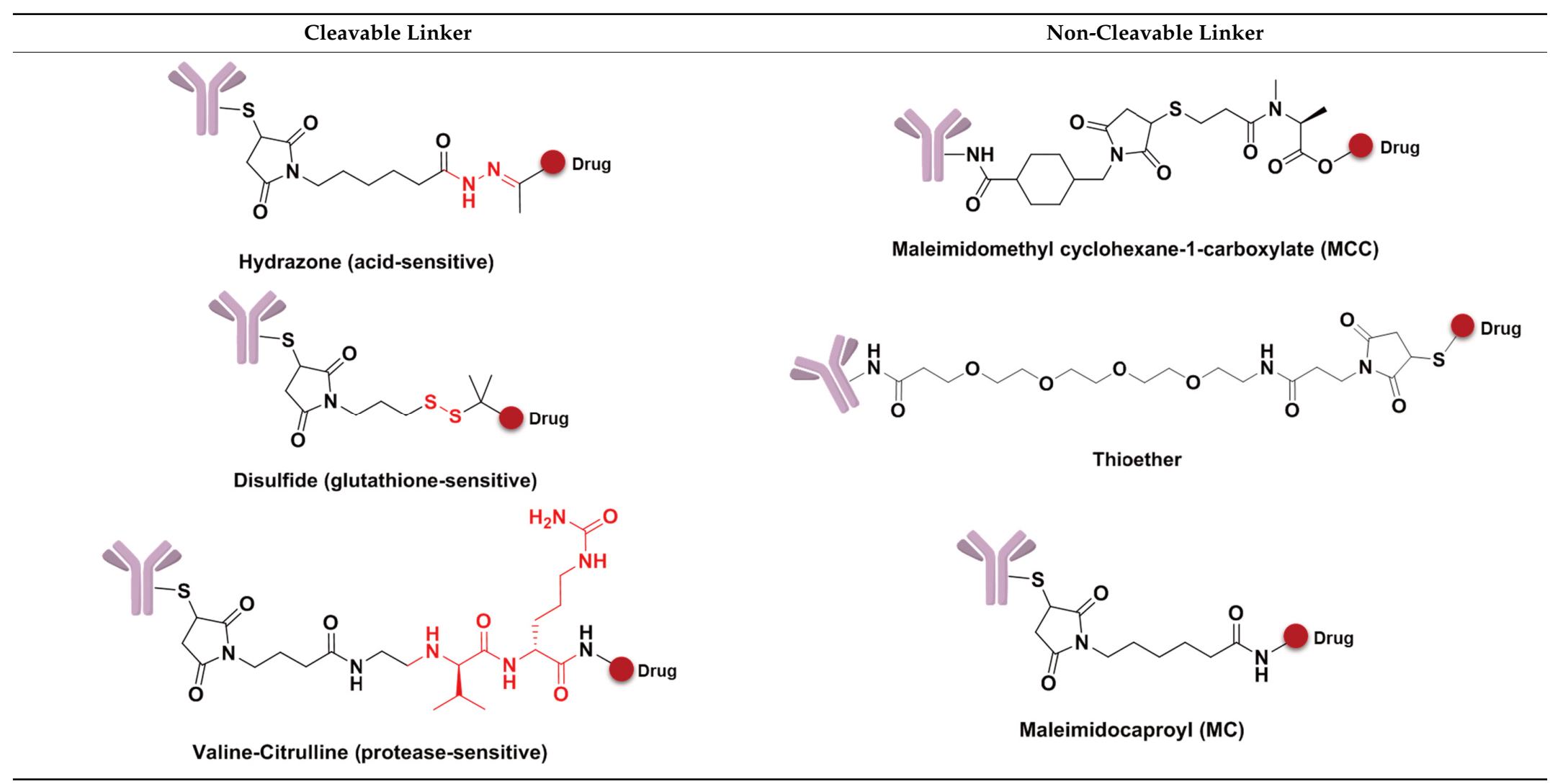




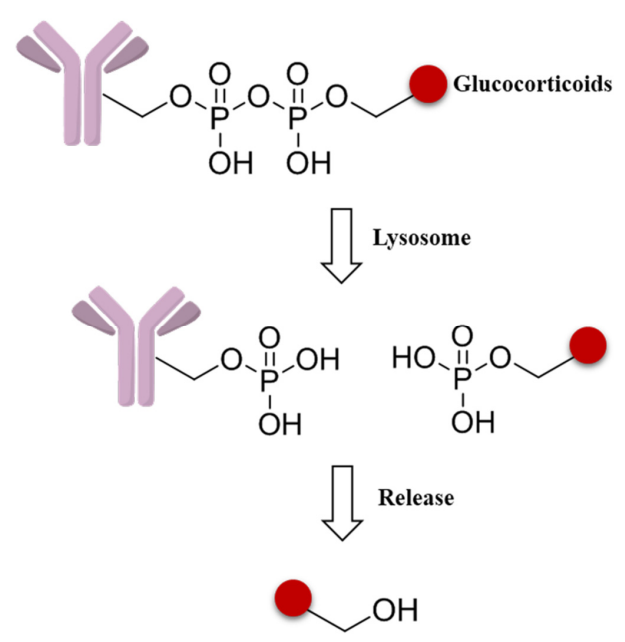

Figure 11. Schematic mechanism of a pyrophosphate ester linker.

\subsubsection{Self-Immolative Spacer}

A self-immolative spacer is the part that still connects to the drug after the trigger activated and ADC cleavaged. It can release drugs through rapidly spontaneous intramolecular reactions, which is equivalent to the function of a prodrug [88]. Para-aminobenzyl (PAB) and heteroatoms are two main structures $[89,90]$. PAB is commonly connected to the peptide linker as the self-immolative spacer that can release active drugs by a 1,6-elimination reaction after the cleavage of the linker (Figure 12). Interestingly, Staben et al. described a bioreversible linkage based on a quaternary ammonium that can be used to connect various tertiary and heteroaryl amines to the antibody. It shows common cleavable ADCs with this new connection are effective and stable in vitro and in vivo (Figure 13). Besides, studies with a tertiary-amine-containing antibody-antibiotic conjugate show that the appropriate stability and release characteristics brought an unexpected improvement in activity over the carbamate [91].

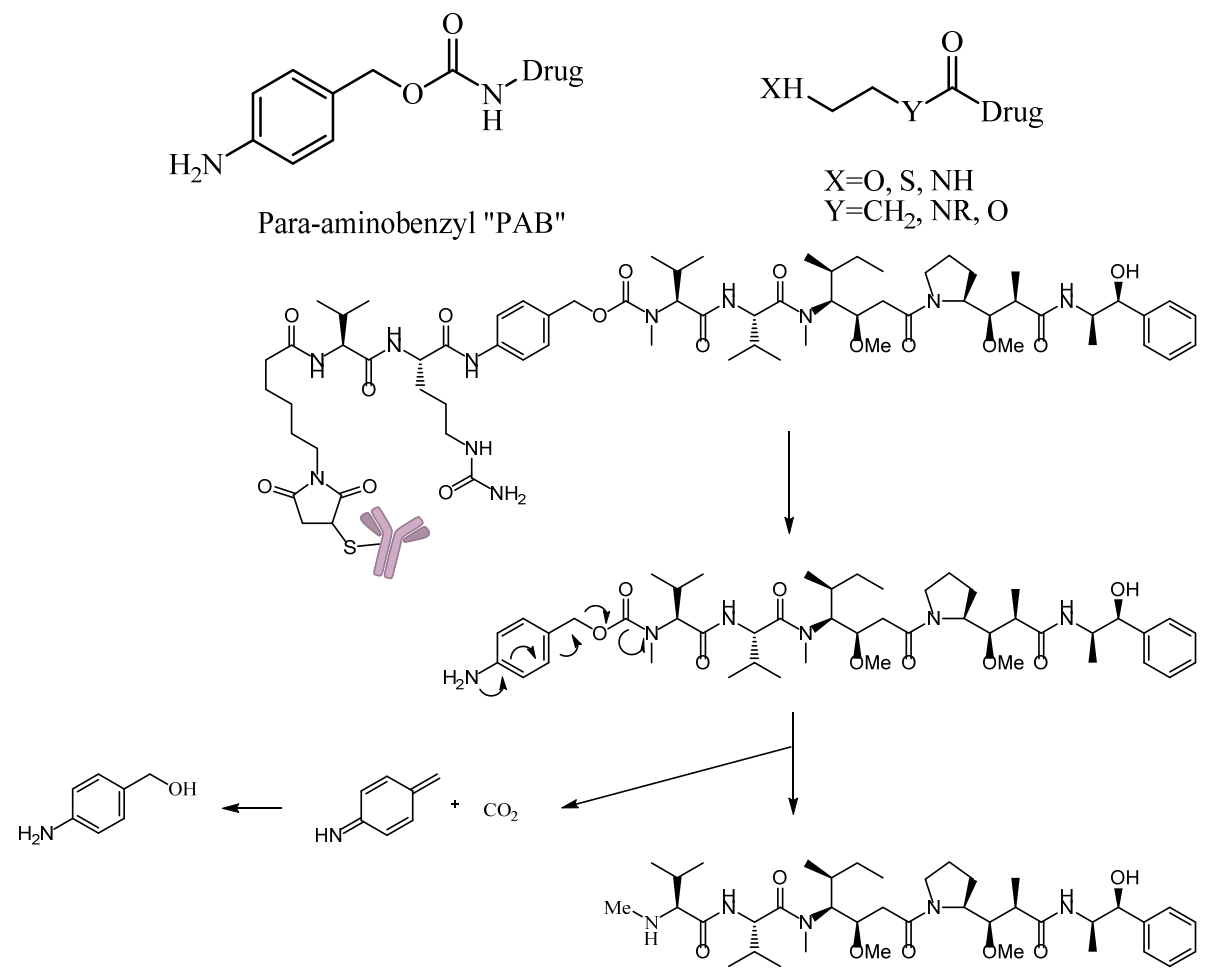

Figure 12. Schematic 1,6-elimination reaction of the self-immolative spacer after cleavage of the linker. 

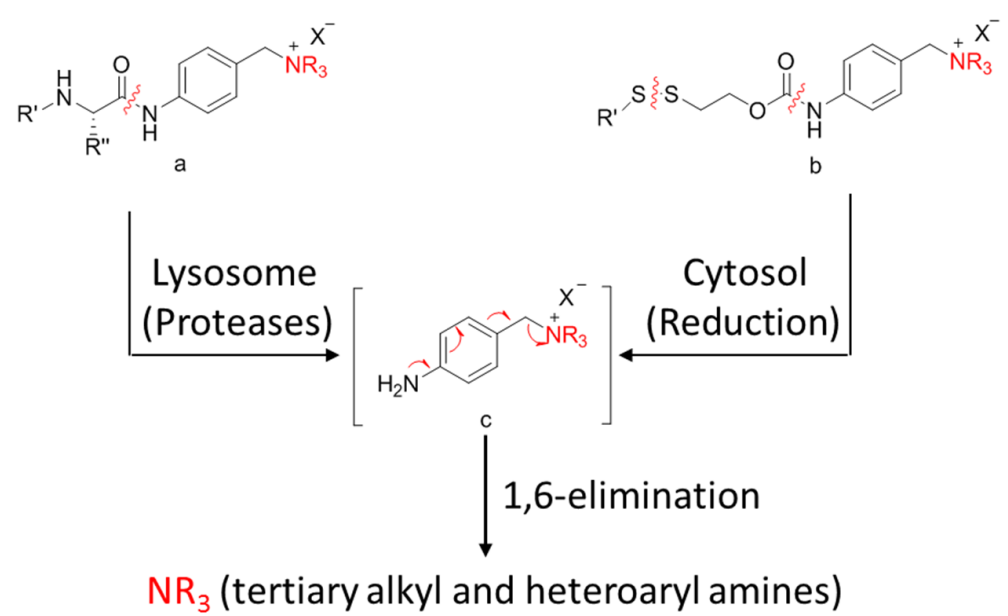

Figure 13. Schematic a bioreversible linkage based on a quaternary ammonium.

\subsection{Cytotoxic Payload}

The cytotoxic drugs, which acting as the payload of ADCs, determine the therapeutic effects of ADC drugs. ADCs belong to proteinic drugs, which can be disaggregated into unconjugated antibodies and toxins or directly disassimilated into some antibody fragments and decomposition products of the drugs during the targeting therapy. Subsequently, the unconjugated antibody and antibody fragments further turn into amino acids under proteolysis. These toxins or drug catabolites can metabolize via cytochrome or non-cytochrome enzymes or are transported by P-gycoprotein and excreted via the biliary or renal pathway (Figure 14). Generally, only $1 \%-2 \%$ of the injected dose of ADCs can effectively reach the intended tumor target and come into action, which are largely different from small molecule drugs for their unique biodistribution and metabolism characters [92]. Therefore, the cytotoxinic drugs usually need very high efficiency and sensitively killing effects on target cells, whose $\mathrm{IC}_{50}$ should be up to $0.01-1 \mathrm{nM}$. Moreover, the payloads need to be stable in blood circulation and lysosomes. A relatively small molecular weight, a long half-life, and weak immunogenicity are also necessary characters for the toxins. For another, $\mathrm{Li}$ et al. studied the bystander effects of two auristatin payloads, MMAE and MMAF, which have similar structures. However, MMAF is more hydrophilic and less membrane permeable than MMAE. The result shows MMAF has a higher cytotoxinic activity than MMAE, consistent with its lower membrane permeability. All of this indicates that membrane permeability and the biophysical properties of the released payload are required for bystander effects [63]. It is particularly important to select appropriate payloads except for linker selection.

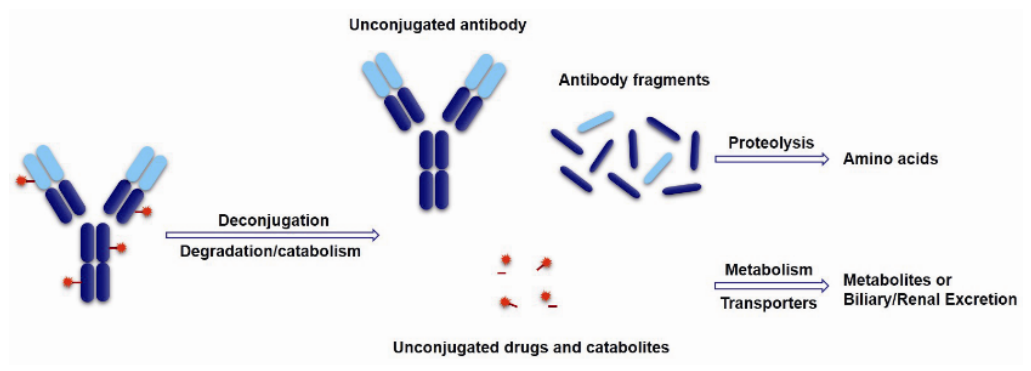

Figure 14. Schematic of theoretical ADCs metabolism pathways.

Currently, there are two main working mechanisms for ADC payloads: (1) disturbing the mitosis process by binding to microtubule targets; and (2) disrupting the DNA duplication process via splitting decomposition and alkylation targets. Some clinical chemotherapeutic drugs including vinca alkaloids, paclitaxel, amethopterin, and doxorubicin, were used as ADC payloads in early stage. However, 
most of these trials were failed attributed to their low curative effect, heterogeneity, and lacking of specific targets [5].

Thus far, all ADCs in the market or used in clinical trial research have adopted the highly toxic natural product or their derivatives as the payloads, of which four toxins, including calicheamicins, duocarmycins, auristatins and maytansines, are heavily relied. The calicheamicins and duocarmycins are DNA damage agents, while the auristatins and maytansines are tubulin inhibitors. Among that, Auristatins applied in ADCs mainly include monomethyl auristatin E (MMAE) and monomethyl auristatin F (MMAF), and the maytansines commonly used as payloads are DM1 and DM4 (Figure 15) [93,94].
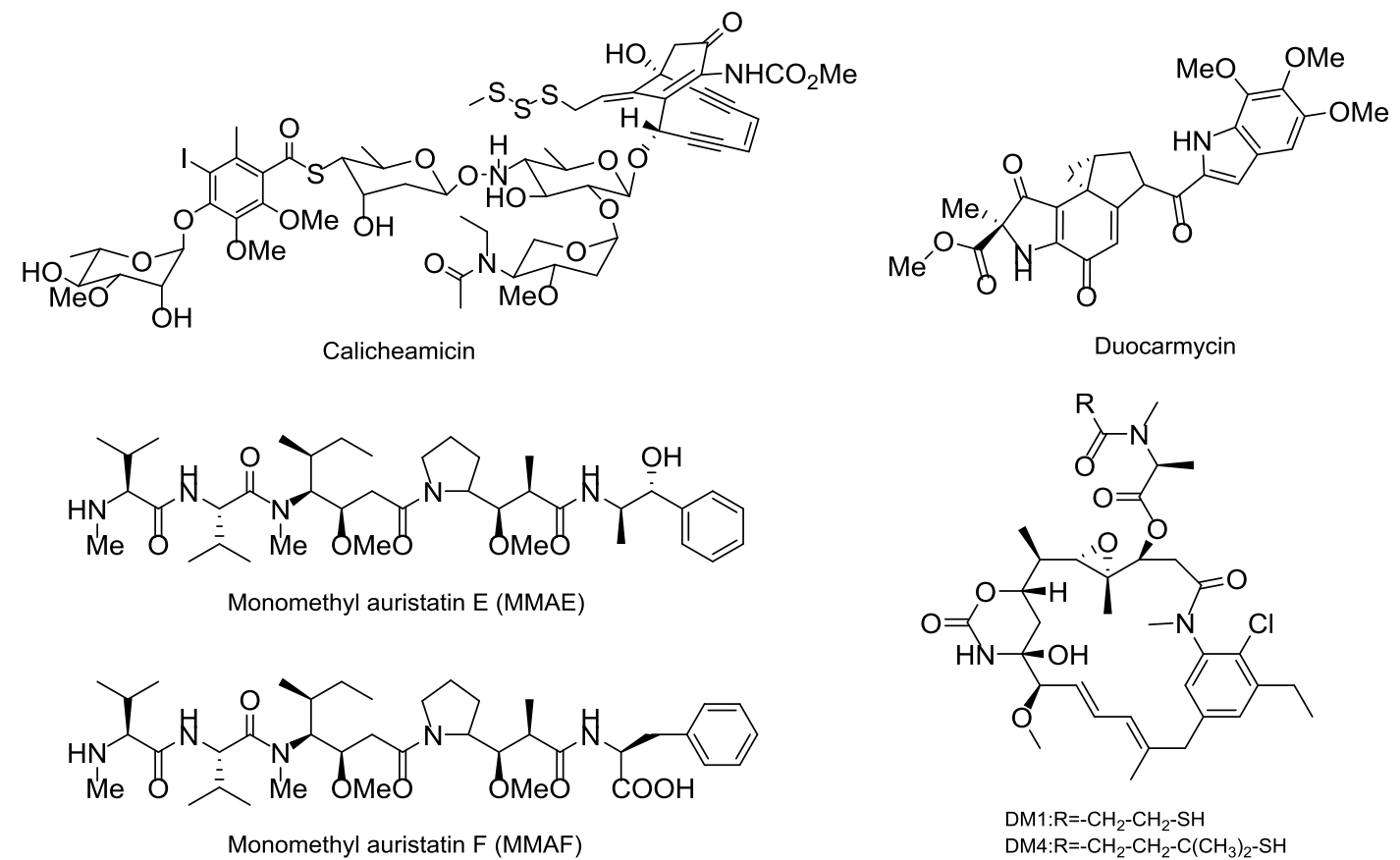

Figure 15. Several representative cytotoxinic drugs used as payloads in ADCs.

\subsubsection{Terrestrial Payloads}

Calicheamicin is a semisynthetic natural product separated from the soil microorganism M. echinospora calichensis that shows subpicomolar grade potency. The aryltetrasaccharide structure in calicheamicins can tightly bind to the minor groove of DNA that eventually results in DNA double-strand break and cell death $[95,96] . N$-acetyl- $\gamma$-calicheamicin is the derivative of calicheamicin that was used as the payload of the approved gemtuzumab ozogamicin (Mylotarg); however, Mylotarg was later withdrawn for unsatisfactory efficacy and safety reasons [97].

Duocarmycin is a derivative of the natural product isolated from the bacteria Streptomyces sp. that can bind to the AT-rich regions at DNA's minor groove and induce irreversible alkylation to disrupt the DNA and cause cell death [98]. A novel prodrug analog of duocarmycin as the payload was connected to a fully human mAb CD70 to get the MDX-1203 that is now in phase I (NCT00944905) [99].

Maytansinoid is an antimitotic tubulin inhibitor derived from maytansine, whose mechanisms are similar to those of vinca alkaloids; however, its efficiency in killing tumor cells in vitro shows 100 to 1000 times more potent than existing anticancer drugs in clinical trials $[100,101]$. $\mathrm{N}^{2^{\prime}}$-deacetyl- $\mathrm{N}^{2^{\prime}}$ (3-mercapto-1-oxopropyl)-maytansine (DM1) and $\mathrm{N}^{2^{\prime}}$-deacetyl- $\mathrm{N}^{2^{\prime}}$-(4-mercapto-4-methyl-1- oxopentyl)maytansine (DM4) are the most commonly synthesized payloads that applied in ADC pipeline [102]. The approved Trastuzumab emtansine (Kadcyla) adopted the DM1, while multiple ADCs in the clinical trials chose DM1 or DM4 as their toxins. 
Except for these four main payloads, there are also some other potential natural products that act as payloads, such as pyrrolobenzodiazepines (PBDs), anthracyclins, amatoxins, epothilones, and so on (Figure 16). PBDs are isolated from Streptomycin sp. and kill tumor cells by covalently binding to the minor groove of DNA. For ADCs in clinical trials, SGN-CD33A and SGN-CD70A adopt PBDs to connect with $\mathrm{mAbs}$ via protease-sensitive linkers and are in phase I/II clinical trials [103]. Anthracyclines are a kind of potent chemotherapeutics derived from Streptomyces peucetius var. caesius, which can be available for treatments of leukemia, lymphoma, breast cancer, ovarian cancer, and many other malignancies [104]. Milatuzumab doxorubicin takes doxorubicin as the payload and is in phase I/II clinical trials in patients with multiple myeloma (NCT01101594). Amatoxins are bicyclic octapeptides discovered from the poisonous mushroom Amanita phalloides, which is an efficient and selective inhibitor of RNA polymerase II to inhibit protein synthesis [105].

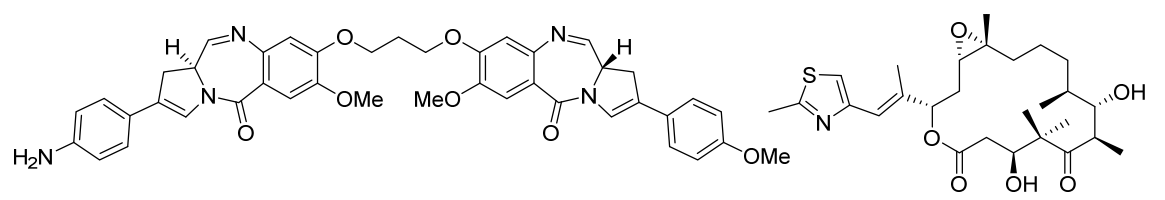

Pyrrolobenzodiazepines

Epothilone B

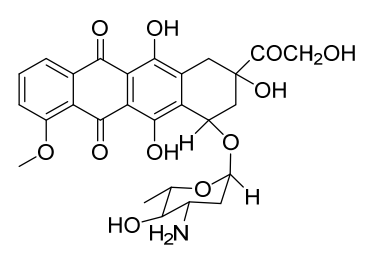

Anthracycline-dxorubicin

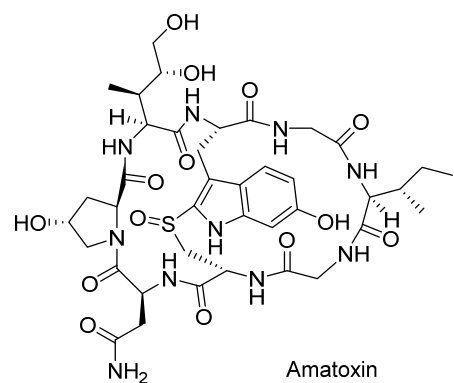

Amatoxin

Figure 16. Structures of several terrestrial payloads.

Recently, anti-PSMA- $\alpha$-amanitin adopts amatoxins as the payload, conjugates to $\mathrm{mAb}$ via a protease-sensitive linker, and exerts favorable antitumor activity. However, details of the amanitin-based ADC have not been disclosed [106]. Compared with other toxins, amatoxins have great potential for their advantages of higher solubility, uniformity, and hydrophilicity. Epothilones are macrolides isolated from Sprangium cellulosum. Epothilones have a similar mechanism compared to that of paclitaxel, and are superior to paclitaxel in terms of antineoplastic activity, safety, solubility, and synthetic methods, which enable them to be the next generation of potentially antimitotic drugs $[107,108]$.

\subsubsection{Marine Payloads}

Marine organisms are regarded as an abundant natural product sources that produce a variety of marine toxins with antineoplastic activity; some toxins even reach nanomolar or picomolar cytotoxic activity [109,110].

Among the marine cytotoxins, auristatins and their derivatives (mainly MMAE and MMAF) take very important position in ADCs payloads. Auristatin is an efficient antimitotic toxin derived from the natural product dolastatin 10, which has an effective pentapeptide with unique amino acids discovered from the sea hare Dolabella auricularia [111]. Auristatins can interact with protein tubulins to inhibit microtubule formation and stop cell division during metaphase. Except for MMAE and MMAF modified from dolastatins 10 [83], plenty of other analogs, such as symplostatins 1, symplostatins 3, and malevamide D, also possess high tumor-killing activity (Figure 17) [112-114]. The brentuximab vedotin (Adcetris), developed by Seattle Genetics, adopted MMAE as the payload, and has been a success story 
with regard to marine drugs used in ADCs [115]. In current clinical trials, approximately half of these ADCs applied MMAE or MMAF as cytotoxinic drug (e.g., Glembatumumab vedotin, DCDS-4501A, AGS-16C3F, etc.).

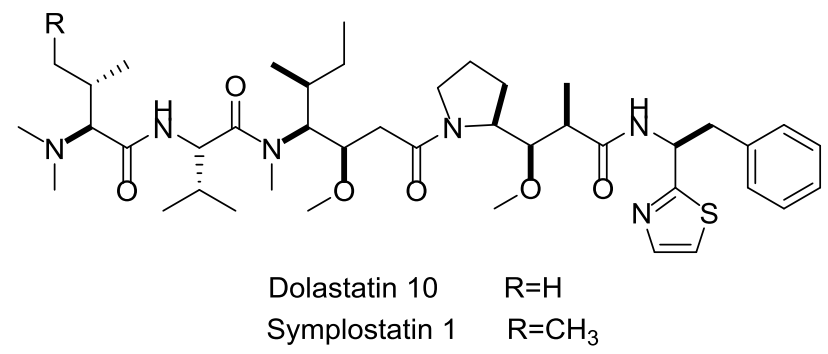

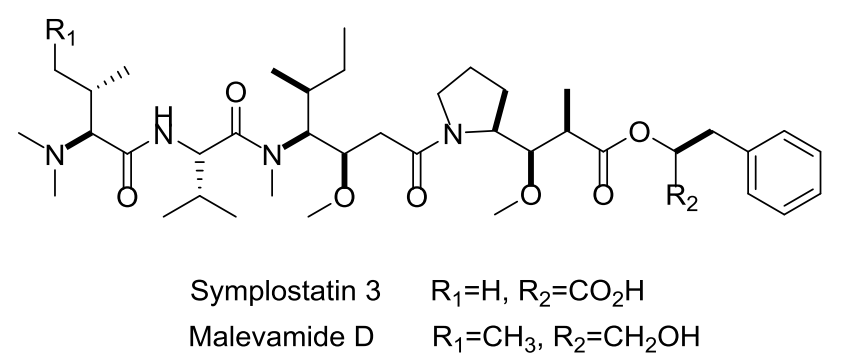

Figure 17. Structures of marine payloads.

\subsubsection{Marine Toxins}

Besides the marine payloads for ADCs, more launched marine toxin drugs are also summarized in this section. Apratoxins are a type of cyclic depsipeptide with potent cytotoxinic activity (Figure 18). Apratoxin A, isolated from ocean cyanobacteria Lyngbya sp., exhibits highly potent antitumor effects via inhibiting cell division during the G1-phase and apoptosis, and displays excellent cytotoxicity in vitro with $\mathrm{IC}_{50}$ values ranging from $0.36 \mathrm{nM}$ in LoVo cancer cells to $0.52 \mathrm{nM}$ in $\mathrm{KB}$ cancer cells $[116,117]$.

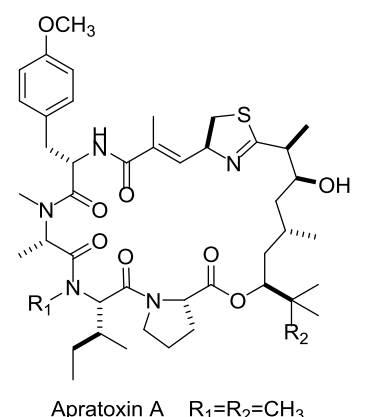

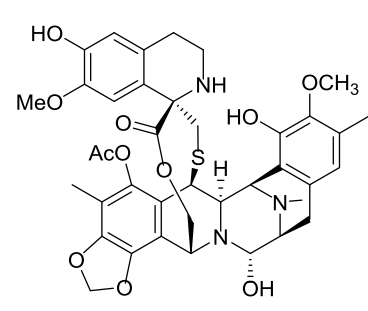

Trabectedin

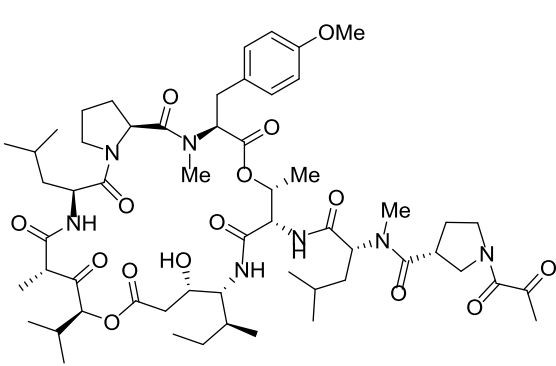

Plitidepsin

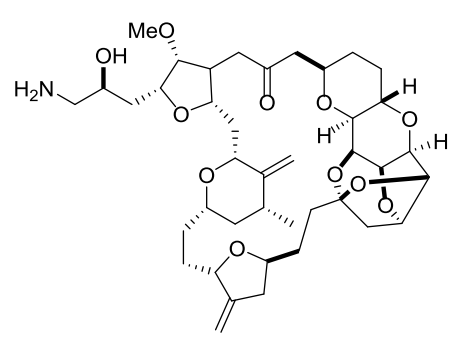

Eribulin

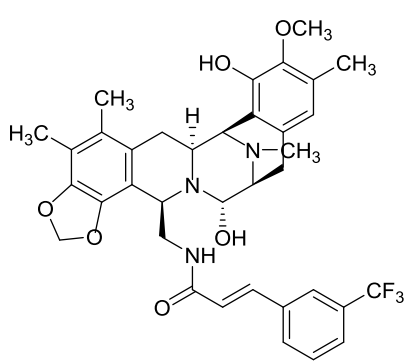

PM00104

Figure 18. Structures of several marine toxins. 
Both Trabectedin (ET-743, Yondelis ${ }^{\circledR}$ ) and Plitidepsin (dehydrodidemnin B, Aplidin ${ }^{\circledR}$ ) were highly potent anticancer drugs isolated from ascidian Ecteinascida turbinate in the Caribbean, which can kill tumor cells by binding to the minor groove of DNA and activating tumor cell apoptosis and multiple mechanisms [118-121]. Specifically, Trabectedin is a well-tolerated drug that lacks cumulative organ-specific toxicity and has completed phase II/III clinical trials for prostate and ovarian cancer and some other solid tumors (NCT00072670, NCT00113607, NCT00786838). Plitidepsin exhibits excellent cytotoxicity in vitro against DLBC and Burkitt's cells at $0.5 \mathrm{nM}$ and $9 \mathrm{nM}$, respectively. The approved indication for Plitidepsin is for the treatment of multiple myeloma, while the research of Plitidepsin against lymphoma, RCC, and other solid tumors are still on the way [122-124].

Eribulin $\left(E 7389\right.$, Halaven $\left.{ }^{\circledR}\right)$ is a highly potent analog of the famous marine natural product halichondrin B, isolated from the sponge Halichondria okadai. It exhibits a potential therapeutic effect against various cancers by microtubule inhibition [125]. Eribulin showed considerable anticancer activity in vitro, with $\mathrm{IC}_{50}$ values ranging from $0.06 \mathrm{nM}$ to $0.3 \mathrm{nM}$ in BT549 cancer cells [126,127], and was approved by FDA for the treatment of metastatic breast cancer in 2010. Further clinical trial studies focusing on other indications, such as lung, ovarian, and pancreatic cancers are ongoing [128].

PM00104 (Zalypsis ${ }^{\circledR}$ ) is an analogs of (-)-Jorumycin, which isolated from a mollusk, Jorunna funebris [129], and exhibits potential anti-proliferative activity at nanomolar concentrations for the treatment of myelomas. The mechanism of PM00104 is similar to that of Trabectedin, including binding to DNA, leading DNA double-strand to breakages, cell cycle arresting in the S-phase, and cell apoptosis [130-132].

\section{Conclusions and Future Directions}

Research findings indicate that marine toxins have immense potential for the development of ADCs and simultaneously draw public attention to marine drug research $[133,134]$. In recent years, ADCs have developed rapidly since Adcetris and Kadcyla were successfully approved, while an increasing number of pharmaceutical companies have come into this research field. In the aspect of ADC design, with the rapid development of oncomolecularbiology, a multitude of specific tumor antigens (receptors, glycoproteins, etc.) are appraised and applied in medical diagnoses, which provides highly possibility for the targeting of anticancer drug development. The monoclonal antibody as the targeting part developed from the initial murine $\mathrm{mAb}$ to currently mature humanized $\mathrm{mAb}$, and even fully human $\mathrm{mAb}$, which immensely ameliorates the immunogenicity problem. In order to implement the transition from hematologic tumors to solid tumors, antibody miniaturization will be a new strategy for developing ADCs. The linker has made remarkable headway, and is now in a comparatively mature stage, while more innovative linkers are being created with modern chemical biology conceptions. Presently, common payloads in the pipeline mainly focus on auristatins and maytansines; however, a series of studies have suggested that more marine toxins in addition to auristatins have the potential to be effective ADC payloads.

The inhomogeneity problem is still the major bottleneck in current ADC development, which negatively affects both pharmaceutical production and quality control. Nonetheless, site-specific conjugation technology has caught numerous pharmaceuticals companies' eyes for solving the inhomogeneity problem to some extent, pointing out the way to further development of ADCs. With the advancement of conjugation technology, a variety of conjugated groups have been designed and connect with many different drugs by the diversified modification of linkers. Multivalent-coupling ADCs will be developed to improve efficacy via connecting several synergistic small molecules in one antibody. ThioBridge ${ }^{\mathrm{TM}}$, GlycoConnect ${ }^{\mathrm{TM}}$, and many other site-specific conjugation technologies will become a prevalent trend and accelerate ADC development into a brand new era.

Acknowledgments: This work was supported financially by the National Natural Science Foundation of China (41306197), National 863 Program (2012AA092105), Guangdong Province Oceanic Administration Commonweal Project (GD2012-D01-001). 
Author Contributions: X.C. and B.-H.J. conceived and designed the experiments; Y.-J.W. performed the experiments; Y.-J.W. and X.C. analyzed the data; Y.-Y.L., X.-Y.L. and X.-L.L. contributed reagents/materials/analysis tools; Y.-J.W. and X.C. wrote the paper.

Conflicts of Interest: The authors declare no conflict of interest.

\section{Abbreviations}

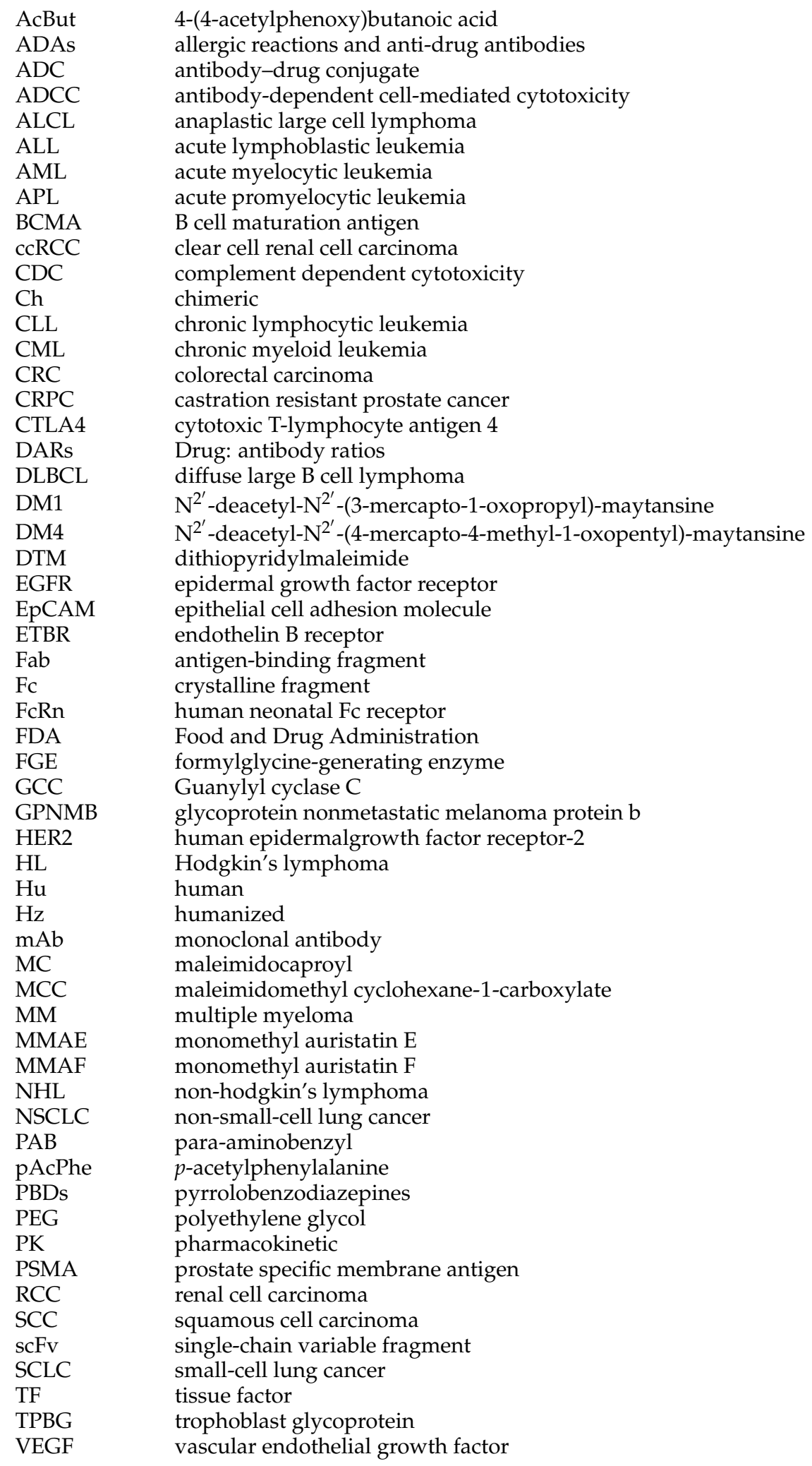




\section{References}

1. Perez, H.L.; Cardarelli, P.M.; Deshpande, S.; Gangwar, S.; Schroeder, G.M.; Vite, G.D.; Borzilleri, R.M. Antibody-drug conjugates: Current status and future directions. Drug Discov. Today 2014, 19, 869-881. [PubMed]

2. Casi, G.; Neri, D. Antibody-drug conjugates: Basic concepts, examples and future perspectives. J Control. Release 2012, 161, 422-428. [PubMed]

3. Scotti, C.; Iamele, L.; Vecchia, L. Antibody-drug conjugates: Targeted weapons against cancer. Antibody Technol. J. 2015, 5. [CrossRef]

4. Hinrichs, M.J.M.; Dixit, R. Antibody drug conjugates: Nonclinical safety considerations. AAPS J. 2015, 17, 1-10. [CrossRef] [PubMed]

5. Teicher, B.A.; Chari, R.V. Antibody conjugate therapeutics: Challenges and potential. Clin. Cancer Res. 2011, 17, 6389-6397. [CrossRef] [PubMed]

6. Senter, P.D.; Sievers, E.L. The discovery and development of brentuximab vedotin for use in relapsed hodgkin lymphoma and systemic anaplastic large cell lymphoma. Nat. Biotechnol. 2012, 30, 631-637. [CrossRef] [PubMed]

7. Sunil, V.; David, M.; Luca, G.; Krop, I.E.; Manfred, W.; José, B.; Mark, P.; Do-Youn, O.; Véronique, D.; Ellie, G. Trastuzumab emtansine for HER2-positive advanced breast cancer. N. Engl. J. Med. 2012, 367, 1783-1791.

8. Hamilton, G.S. Antibody-drug conjugates for cancer therapy: The technological and regulatory challenges of developing drug-biologic hybrids. Biologicals 2015, 43, 318-332. [CrossRef] [PubMed]

9. Singh, S.K.; Luisi, D.L.; Pak, R.H. Antibody-drug conjugates: Design, formulation and physicochemical stability. Pharm. Res. 2015, 32, 3541-3571. [CrossRef] [PubMed]

10. Mccombs, J.R.; Owen, S.C. Antibody drug conjugates: Design and selection of linker, payload and conjugation chemistry. AAPS J. 2015, 17, 339-351. [CrossRef] [PubMed]

11. Beck, A.; Haeuw, J.F.; Wurch, T.; Goetsch, L.; Bailly, C.; Corvaïa, N. The next generation of antibody-drug conjugates comes of age. Discov. Med. 2010, 10, 329-339. [PubMed]

12. Ritter, A. Antibody-drug conjugates: Looking ahead to an emerging class of biotherapeutic. Pharm. Technol. 2012, 36, 42-47.

13. Nelson, A.L.; Eugen, D.; Reichert, J.M. Development trends for human monoclonal antibody therapeutics. Nat. Rev. Drug Discov. 2010, 9, 767-774. [CrossRef] [PubMed]

14. Grewal, I.S. CD70 as a therapeutic target in human malignancies. Expert Opin. Ther. Targets 2008, 12, 341-351. [CrossRef] [PubMed]

15. Cardarelli, P.; King, D.; Terrett, J.; Gangwar, S.; Cohen, L.; Pan, C.; Rao, C.; Deshpande, S.; Vangipuram, R.; Passmore, D. Efficacy and safety of a human anti-CD70 antibody-MGBA conjugate. Cancer Res. 2008, 68, 4061.

16. Haffner, M.C.; Kronberger, I.E.; Ross, J.S.; Sheehan, C.E.; Matthias, Z.; Gilbert, M.; Dietmar, O.; Bettina, Z.; Christian, E.; Yang, X.J. Prostate-specific membrane antigen expression in the neovasculature of gastric and colorectal cancers. Hum. Pathol. 2009, 40, 1754-1761. [CrossRef] [PubMed]

17. Liu, H.; Moy, P.; Kim, S.; Xia, Y.; Rajasekaran, A.; Navarro, V.; Knudsen, B.; Bander, N.H. Monoclonal antibodies to the extracellular domain of prostate-specific membrane antigen also react with tumor vascular endothelium. Cancer Res. 1997, 57, 3629-3634. [PubMed]

18. Petrylak, D.P.; Vogelzang, N.J.; Chatta, G.S.; Fleming, M.T.; Smith, D.C.; Appleman, L.J.; Arif Hussain, M.M.; Singh, P.; Tagawa, S.T.; Gore, I.; et al. A phase 2 study of prostate specific membrane antigen antibody drug conjugate (PSMA ADC) in patients (pts) with progressive metastatic castration-resistant prostate cancer (mCRPC) following abiraterone and/or enzalutamide (abi/enz). J. Clin. Oncol. 2015, 33, 144. [CrossRef]

19. Petrylak, D.; Smith, D.C.; Appleman, L.J.; Fleming, M.; Hussain, A.; Dreicer, R.; Sartor, O.; Shore, N.; Vogelzang, N.J.; Youssoufian, H. A phase II trial of prostate-specific membrane antigen antibody drug conjugate (PSMA ADC) in taxane-refractory metastatic castration-resistant prostate cancer (mCRPC). Eur. Urol. Suppl. 2010, 154, 5-6.

20. Mizuki, T.; Jin-Sung, C.; Hideo, A.; Cruz, P.D.; Kiyoshi, A. DC-HIL/glycoprotein Nmb promotes growth of melanoma in mice by inhibiting the activation of tumor-reactive T cells. Cancer Res. 2010, 70, 5778-5787.

21. Gaboury, H.M.P.L. Glycoprotein nonmetastatic $b$ is an independent prognostic indicator of recurrence and a novel therapeutic target in breast cancer. Clin. Cancer Res. 2010, 16, 2147-2156. 
22. Kuan, C.T.; Wakiya, K.; Dowell, J.M.; Herndon, J.E.; Reardon, D.A.; Graner, M.W.; Riggins, G.J.; Wikstrand, C.J.; Bigner, D.D. Glycoprotein nonmetastatic melanoma protein b, a potential molecular therapeutic target in patients with glioblastoma multiforme. Clin. Cancer Res. 2006, 12, 1970-1982. [CrossRef]

23. Kam Fai, T.; Michael, J.; Pollack, V.A.; Mccabe, D.A.; Shadish, M.L.; Khramtsov, N.V.; Hackett, C.S.; Shenoy, S.G.; Bing, K.; Boldog, F.L. Cr011, a fully human monoclonal antibody-auristatin e conjugate, for the treatment of melanoma. Clin. Cancer Res. 2006, 12, 1373-1382.

24. Hamid, O.; Sznol, M.; Pavlick, A.C.; Kluger, H.M.; Kim, K.B.; Boasberg, P.D.; Simantov, R.; Davis, T.A.; Crowley, E.; Hwu, P. Frequent dosing and GPNMB expression with CDX-011 (CR011-vcMMAE), an antibody-drug conjugate (ADC), in patients with advanced melanoma. J. Clin. Oncol. 2010, $28,8525$.

25. Barrow, K.M.; Ward, C.M.; Rutter, J.; Ali, S.; Stern, P.L. Embryonic expression of murine 5 T4 oncofoetal antigen is associated with morphogenetic events at implantation and in developing epithelia. Dev. Dyn. 2005, 233, 1535-1545. [CrossRef] [PubMed]

26. Wrigley, E.; Mcgown, A.T.; Rennison, J.; Swindell, R.; Crowther, D.; Starzynska, T.; Stern, P.L. 5T4 oncofetal antigen expression in ovarian carcinoma. Int. J. Gynecol. Cancer 1995, 5, 269-274. [CrossRef] [PubMed]

27. Starzynska, T.; Marsh, P.J.; Schofield, P.F.; Roberts, S.A.; Myers, K.A.; Stern, P.L. Prognostic significance of 5T4 oncofetal antigen expression in colorectal carcinoma. Br. J. Cancer 1994, 69, 899-902. [CrossRef] [PubMed]

28. Marc, D.; Geles, K.G.; Follettie, M.T.; Ping, Y.; Michelle, B.; Jonathon, G.; Dijoseph, J.F.; Maha, K.; Shuguang, H.; Veronica, D. Delineation of a cellular hierarchy in lung cancer reveals an oncofetal antigen expressed on tumor-initiating cells. Cancer Res. 2011, 71, 4236-4246.

29. Sapra, P.; Damelin, M.; Dijoseph, J.; Marquette, K.; Geles, K.G.; Golas, J.; Dougher, M.; Narayanan, B.; Giannakou, A.; Khandke, K. Long-term tumor regression induced by an antibody-drug conjugate that targets 5T4, an oncofetal antigen expressed on tumor-initiating cells. Mol. Cancer Ther. 2013, 12, 38-47. [CrossRef] [PubMed]

30. Goldmacher, V.S.; Kovtun, Y.V. Antibody-drug conjugates: Using monoclonal antibodies for delivery of cytotoxic payloads to cancer cells. Ther. Deliv. 2011, 2, 397-416. [CrossRef] [PubMed]

31. Adair, J.R.; Howard, P.W.; Hartley, J.A.; Williams, D.G.; Chester, K.A. Antibody-drug conjugates-A perfect synergy. Expert Opin. Biol. Ther. 2012, 12, 1191-1206. [CrossRef] [PubMed]

32. Stern, M.; Herrmann, R. Overview of monoclonal antibodies in cancer therapy: Present and promise. Crit. Rev. Oncol./Hematol. 2005, 54, 11-29. [CrossRef] [PubMed]

33. Natsume, A.; Takamura, I.H.; Nakagawa, T. Engineered antibodies of $\mathrm{IgG}_{1} / \mathrm{IgG}_{3}$ mixed isotype with enhanced cytotoxic activities. Cancer Res. 2008, 68, 3863-3872. [CrossRef] [PubMed]

34. Reichert, J.M.; Valge-Archer, V.E. Development trends for monoclonal antibody cancer therapeutics. Dressnature Rev. Drug Discov. 2007, 6, 349-356. [CrossRef] [PubMed]

35. Law, C.; Cerveny, C.; Gordon, K.; Klussman, K.; Mixan, B.; Chace, D.; Meyer, D.; Doronina, S. Efficient elimination of B-lineage lymphomas by anti-CD20-auristatin conjugates. Clin. Cancer Res. 2004, 10, 7842-7851. [CrossRef] [PubMed]

36. Ober, R.J.; Radu, C.G.; Ghetie, V.; Ward, E.S. Differences in promiscuity for antibody-FcRn interactions across species: Implications for therapeutic antibodies. Int. Immunol. 2001, 13, 1551-1559. [CrossRef] [PubMed]

37. Morrison, S.L.; Johnson, M.J.; Herzenberg, L.A.; Oi, V.T. Chimeric human antibody molecules: Mouse antigen-binding domains with human constant region domains. Proc. Natl. Acad. Sci. USA 1984, 81, 6851-6855. [CrossRef] [PubMed]

38. Presta, L.G. Engineering of therapeutic antibodies to minimize immunogenicity and optimize function $九$. Adv. Drug Deliv. Rev. 2006, 58, 640-656. [CrossRef] [PubMed]

39. Jones, P.T.; Dear, P.H.; Foote, J.; Neuberger, M.S.; Winter, G. Replacing the complementarity-determining regions in a human antibody with those from a mouse. Nature 1986, 321, 522-525. [CrossRef] [PubMed]

40. Mccafferty, J.; Griffiths, A.D.; Winter, G.; Chiswell, D.J. Phage antibodies: Filamentous phage displaying antibody variable domains. Nature 1990, 348, 552-554. [CrossRef] [PubMed]

41. René Michael, H.; Cohen, E.H.; Rachel Baribault, K.; Kristin, R.; Sonia, S.; Shannon, H.; Louise, R.; Nicolas, F.; Marc, D.; Henk, P. Generation of high-affinity human antibodies by combining donor-derived and synthetic complementarity-determining-region diversity. Nat. Biotechnol. 2005, 23, 344-348.

42. Lonberg, N.; Taylor, L.D.; Harding, F.A.; Trounstine, M.; Higgins, K.M.; Schramm, S.R.; Kuo, C.C.; Mashayekh, R.; Wymore, K.; Mccabe, J.G. Antigen-specific human antibodies from mice comprising four distinct genetic modifications. Nature 1994, 368, 856-859. [CrossRef] [PubMed] 
43. Baker, M.P.; Reynolds, H.M.; Lumicisi, B.; Bryson, C.J. Immunogenicity of protein therapeutics: The key causes, consequences and challenges. Exp. Cell Res. 2010, 50, 349-354. [CrossRef] [PubMed]

44. Sliwkowski, M.X.; Ira, M. Antibody therapeutics in cancer. Science 2013, 341, 1192-1198. [CrossRef] [PubMed]

45. Schmidt, M.M.; Wittrup, K.D. A modeling analysis of the effects of molecular size and binding affinity on tumor targeting. Mol. Cancer Ther. 2009, 8, 2861-2871. [CrossRef] [PubMed]

46. Reichert, J.M.; Rosensweig, C.J.; Faden, L.B.; Dewitz, M.C. Monoclonal antibody successes in the clinic. Nat. Biotechnol. 2005, 23, 1073-1078. [CrossRef] [PubMed]

47. Sievers, E.L.; Senter, P.D. Antibody-drug conjugates in cancer therapy. Annu. Rev. Med. 2013, 64, 15-29. [CrossRef] [PubMed]

48. Jefferis, R. Isotype and glycoform selection for antibody therapeutics. Arch. Biochem. Biophys. 2012, 526, 159-166. [CrossRef] [PubMed]

49. Mark, R. Genentech's glyco-engineered antibody to succeed rituxan. Nat. Biotechnol. 2014, 32, 6-7.

50. Mikkel Wandahl, P.; Helle Jane, J.; Klaus, K.; Adam, H.; Charles, P.; John, S.; Rensen, H.; Michael, K. Sym004: A novel synergistic anti-epidermal growth factor receptor antibody mixture with superior anticancer efficacy. Cancer Res. 2010, 70, 588-597.

51. Linke, R.; Klein, A.; Seimetz, D. Catumaxomab: Clinical development and future directions. MAbs 2010, 2, 129-136. [CrossRef] [PubMed]

52. Saga, T.; Neumann, R.D.; Heya, T.; Sato, J.; Kinuya, S.; Le, N.; Paik, C.H.; Weinstein, J.N. Targeting cancer micrometastases with monoclonal antibodies: A binding-site barrier. Proc. Natl. Acad. Sci. USA 1995, 92, 8999-9003. [CrossRef] [PubMed]

53. Rudnick, S.I.; Lou, J.; Shaller, C.C.; Tang, Y.; Klein-Szanto, A.J.; Weiner, L.M.; Marks, J.D.; Adams, G.P. Influence of affinity and antigen internalization on the uptake and penetration of anti-HER2 antibodies in solid tumors. Cancer Res. 2011, 71, 2250-2259. [CrossRef] [PubMed]

54. Philipp, H.; Hudson, P.J. Engineered antibody fragments and the rise of single domains. Nat. Biotechnol. 2005, 23, 1126-1136.

55. Borsi, L.; Balza, E.; Bestagno, M.; Castellani, P.; Carnemolla, B.; Biro, A.; Leprini, A.; Sepulveda, J.; Burrone, O.; Neri, D.; et al. Selective targeting of tumoral vasculature: Comparison of different formats of an antibody (L19) to the ED-B domain of fibronectin. Int. J. Cancer 2002, 102, 75-85. [CrossRef] [PubMed]

56. Berndorff, D.; Borkowski, S.; Sieger, S.; Rother, A.; Friebe, M.; Viti, F.; Hilger, C.S.; Cyr, J.E.; Dinkelborg, L.M. Radioimmunotherapy of solid tumors by targeting extra domain $b$ fibronectin: Identification of the best-suited radioimmunoconjugate. Clin. Cancer Res. 2005, 11, 7053s-7063s. [CrossRef] [PubMed]

57. Adams, G.P.; Schier, R.; Mccall, A.M.; Simmons, H.H.; Horak, E.M.; Alpaugh, R.K.; Marks, J.D.; Weiner, L.M. High affinity restricts the localization and tumor penetration of single-chain $\mathrm{fv}$ antibody molecules. Cancer Res. 2001, 61, 4750-4755.

58. Zahnd, C.; Kawe, M.; Stumpp, M.T.; de Pasquale, C.; Tamaskovic, R.; Nagy-Davidescu, G.; Dreier, B.; Schibli, R.; Binz, H.K.; Waibel, R.; et al. Efficient tumor targeting with high-affinity designed ankyrin repeat proteins: Effects of affinity and molecular size. Cancer Res. 2010, 70, 1595-1605. [CrossRef] [PubMed]

59. Acchione, M.; Kwon, H.; Jochheim, C.M.; Atkins, W.M. Impact of linker and conjugation chemistry on antigen binding, Fc receptor binding and thermal stability of model antibody-drug conjugates. MAbs 2012, 4, 362-372. [CrossRef] [PubMed]

60. Sun, M.M.C.; Beam, K.S.; Cerveny, C.G.; Hamblett, K.J.; Blackmore, R.S. Reduction-alkylation strategies for the modification of specific monoclonal antibody bisulfides. Bioconj. Chem. 2005, 16, 1282-1290. [CrossRef] [PubMed]

61. Panowksi, S.; Bhakta, S.; Raab, H.; Polakis, P.; Junutula, J.R. Site-specific antibody drug conjugates for cancer therapy. MAbs 2014, 6, 34-45.

62. Dere, R.; Yi, J.H.; Lei, C.; Saad, O.M.; Huang, C.; Li, Y.; Baudys, J.; Kaur, S. Pk assays for antibody-drug conjugates: Case study with ado-trastuzumab emtansine. Bioanalysis 2013, 5, 1025-1040. [CrossRef] [PubMed]

63. Li, F.; Emmerton, K.K.; Jonas, M.; Zhang, X.; Miyamoto, J.B.; Setter, J.R.; Nicholas, N.D.; Okeley, N.M.; Lyon, R.P.; Benjamin, D.R.; et al. Intracellular released payload influences potency and bystander-killing effects of antibody-drug conjugates in preclinical models. Cancer Res. 2016, 76, 2710-2719. [CrossRef] [PubMed] 
64. Lyons, A.; King, D.J.; Owens, R.J.; Yarranton, G.T.; Millican, A.; Whittle, N.R.; Adair, J.R. Site-specific attachment to recombinant antibodies via introduced surface cysteine residues. Protein Eng. 1990, 3, 703-708. [CrossRef] [PubMed]

65. Axup, J.Y.; Bajjuri, K.M.; Ritland, M.; Hutchins, B.M.; Kim, C.H.; Kazane, S.A.; Halder, R.; Forsyth, J.S.; Santidrian, A.F.; Stafin, K.; et al. Synthesis of site-specific antibody-drug conjugates using unnatural amino acids. Proc. Natl. Acad. Sci. USA 2012, 109, 16101-16106. [CrossRef] [PubMed]

66. Drake, P.M.; Albers, A.E.; Baker, J.; Banas, S.; Barfield, R.M.; Bhat, A.S.; de Hart, G.W.; Garofalo, A.W.; Holder, P.; Jones, L.C. Aldehyde tag coupled with HIPS chemistry enables the production of ADCs conjugated site-specifically to different antibody regions with distinct in vivo efficacy and Pk outcomes. Bioconj. Chem. 2014, 25, 1331-1341. [CrossRef] [PubMed]

67. Badescu, G.; Bryant, P.; Bird, M.; Henseleit, K.; Swierkosz, J.; Parekh, V.; Tommasi, R.; Pawlisz, E.; Jurlewicz, K.; Farys, M. Bridging disulfides for stable and defined antibody drug conjugates. Bioconj. Chem. 2014, 25, 1124-1136. [CrossRef] [PubMed]

68. Patterson, J.T.; Asano, S.; Li, X.; Rader, C.; Barbas, C.F., 3rd. Improving the serum stability of site-specific antibody conjugates with sulfone linkers. Bioconj. Chem. 2014, 25, 1402-1407. [CrossRef] [PubMed]

69. Van Geel, R.; Wijdeven, M.A.; Heesbeen, R.; Verkade, J.M.; Wasiel, A.A.; van Berkel, S.S.; van Delft, F.L. Chemoenzymatic conjugation of toxic payloads to the globally conserved N-glycan of native MAbs provides homogeneous and highly efficacious antibody-drug conjugates. Bioconj. Chem. 2015, 26, 2233-2242. [CrossRef] [PubMed]

70. Okeley, N.M.; Alley, S.C.; Anderson, M.E.; Boursalian, T.E.; Burke, P.J.; Emmerton, K.M.; Jeffrey, S.C.; Klussman, K.; Law, C.L.; Sussman, D. Development of orally active inhibitors of protein and cellular fucosylation. Proc. Natl. Acad. Sci. USA 2013, 110, 5404-5409. [CrossRef] [PubMed]

71. Besanceney-Webler, C.; Hao, J.; Wei, W.; Baughn, A.D.; Peng, W. Metabolic labeling of fucosylated glycoproteins in bacteroidales species. Bioorg. Med. Chem. Lett. 2011, 21, 4989-4992. [CrossRef] [PubMed]

72. Esam, A.S.; Jean-Luc, C.; Christina, L.M.; Sheng-Kai, W.; Chi-Huey, W.; Haltiwanger, R.S. 6-Alkynyl fucose is a bioorthogonal analog for $O$-fucosylation of epidermal growth factor-like repeats and thrombospondin Type-1 repeats by protein O-fucosyltransferases 1 and 2. Glycobiology 2013, 23, 188-198.

73. Jain, N.; Smith, S.W.; Ghone, S.; Tomczuk, B. Current adc linker chemistry. Pharm. Res. 2015, 32, $3526-3540$. [CrossRef] [PubMed]

74. Ducry, L.; Stump, B. Antibody-drug conjugates: Linking cytotoxic payloads to monoclonal antibodies. Bioconj. Chem. 2010, 21, 5-13. [CrossRef] [PubMed]

75. Lambert, J.M.; Chari, R.V.J. Ado-trastuzumab emtansine (T-DM1): An antibody-drug conjugate (ADC) for HER2-positive breast cancer. J. Med. Chem. 2014, 57, 6949-6964. [CrossRef] [PubMed]

76. Nolting, B. Linker technologies for antibody-drug conjugates. Methods Mol. Biol. 2013, 1045, 71-100. [PubMed]

77. Lyon, R.P.; Setter, J.R.; Bovee, T.D.; Doronina, S.O.; Hunter, J.H.; Anderson, M.E.; Balasubramanian, C.L.; Duniho, S.M.; Leiske, C.I.; Fu, L. Self-hydrolyzing maleimides improve the stability and pharmacological properties of antibody-drug conjugates. Nat. Biotechnol. 2014, 32, 1059-1062. [CrossRef] [PubMed]

78. Burke, P.J.; Senter, P.D.; Meyer, D.W.; Miyamoto, J.B.; Anderson, M.; Toki, B.E.; Manikumar, G.; Wani, M.C.; Kroll, D.J.; Jeffrey, S.C. Design, synthesis, and biological evaluation of antibody-drug conjugates comprised of potent camptothecin analogues. Bioconj. Chem. 2009, 20, 1242-1250. [CrossRef] [PubMed]

79. Hitchcock, S.A. Structural modifications that alter the $p$-glycoprotein efflux properties of compounds. J. Med. Chem. 2012, 55, 4877-4895. [CrossRef] [PubMed]

80. Zhao, R.Y.; Wilhelm, S.D.; Charlene, A.; Gregory, J.; Leece, B.A.; Lazar, A.C.; Goldmacher, V.S.; Rajeeva, S.; Yelena, K.; Widdison, W.C. Synthesis and evaluation of hydrophilic linkers for antibody-maytansinoid conjugates. J. Med. Chem. 2011, 54, 3606-3623. [CrossRef] [PubMed]

81. Ritchie, M.; Tchistiakova, L.; Scott, N. Implications of receptor-mediated endocytosis and intracellular trafficking dynamics in the development of antibody drug conjugates. MAbs 2013, 5, 13-21. [CrossRef] [PubMed]

82. Dubowchik, G.M.; Firestone, R.A.; Padilla, L.; Willner, D.; Hofstead, S.J.; Mosure, K.; Knipe, J.O.; Lasch, S.J.; Trail, P.A. Cathepsin b-labile dipeptide linkers for lysosomal release of doxorubicin from internalizing immunoconjugates: Model studies of enzymatic drug release and antigen-specific in vitro anticancer activity. Bioconj. Chem. 2002, 13, 855-869. [CrossRef] 
83. Doronina, S.O.; Toki BETorgov, M.Y.; Mendelsohn, B.A.; Cerveny, C.G.; Chace, D.F. Development of potent monoclonal antibody auristatin conjugates for cancer therapy. Nat. Biotechnol. 2003, 21, 778-784. [CrossRef] [PubMed]

84. Doronina, S.O.; Meyer, B.D.W. Novel peptide linkers for highly potent antibody-Auristatin conjugate. Bioconj. Chem. 2008, 19, 1960-1963. [CrossRef] [PubMed]

85. Jeffrey, S.C.; Andreyka, J.B.; Bernhardt, S.X.; Kissler, K.M.; Kline, T.; Lenox, J.S.; Moser, R.F.; Nguyen, M.T.; Okeley, N.M.; Stone, I.J. Development and properties of beta-glucuronide linkers for monoclonal antibody-drug conjugates. Bioconj. Chem. 2006, 17, 831-840. [CrossRef] [PubMed]

86. Chari, R.V.J. Targeted cancer therapy: Conferring specificity to cytotoxic drugs. ChemInform 2008, 41, 98-107. [CrossRef] [PubMed]

87. Kern, J.C.; Cancilla, M.; Dooney, D.; Kwasnjuk, K.; Zhang, R.; Beaumont, M.; Figueroa, I.; Hsieh, S.; Liang, L.; Tomazela, D. Discovery of pyrophosphate diesters as tunable, soluble and bioorthogonal linkers for site-specific antibody-drug conjugates. J. Am. Chem. Soc. 2016, 138, 1430-1445. [CrossRef] [PubMed]

88. Blencowe, C.A. Self-immolative linkers in polymeric delivery systems. Polym. Chem. 2011, 4, 773-790. [CrossRef]

89. Toki, B.E.; Cerveny, C.G.; Wahl, A.F.; Senter, P.D. Protease-mediated fragmentation of $p$-amidobenzyl ethers: A new strategy for the activation of anticancer prodrugs. J. Org. Chem. 2002, 67, 1866-1872. [CrossRef] [PubMed]

90. Dewit, M.A.; Gillies, E.R. Design, synthesis, and cyclization of 4-aminobutyric acid derivatives: Potential candidates as self-immolative spacers. Org. Biomol. Chem. 2011, 9, 1846-1854. [CrossRef] [PubMed]

91. Staben, L.R.; Koenig, S.G.; Lehar, S.M.; Vandlen, R.; Zhang, D.; Chuh, J.; Yu, S.F.; Ng, C.; Guo, J.; Liu, Y.; et al. Targeted drug delivery through the traceless release of tertiary and heteroaryl amines from antibody-drug conjugates. Nat. Chem. 2016, 8, 1112-1119. [CrossRef] [PubMed]

92. Lin, K.; Tibbitts, J. Pharmacokinetic considerations for antibody drug conjugates. Pharm. Res. 2012, 29, 2354-2366. [CrossRef] [PubMed]

93. Flygare, J.A.; Pillow, T.H.; Aristoff, P. Antibody-drug conjugates for the treatment of cancer. Chem. Biol. Drug Des. 2013, 81, 113-121. [CrossRef] [PubMed]

94. Gerber, H.P.; Koehn, F.E.; Abraham, R.T. The antibody-drug conjugate: An enabling modality for natural product-based cancer therapeutics. Nat. Prod. Rep. 2013, 30, 625-639. [CrossRef]

95. Dosio, F.; Brusa, P.; Cattel, L. Immunotoxins and anticancer drug conjugate assemblies: The role of the linkage between components. Toxins 2011, 3, 848-883. [CrossRef]

96. Smith, A.L.; Nicolaou, K.C. The enediyne antibiotics. J. Med. Chem. 1996, 39, 2103-2117. [CrossRef] [PubMed]

97. Giles, F.J.; Kantarjian, H.M.; Kornblau, S.M.; Thomas, D.A.; Garcia-Manero, G.; Waddelow, T.A.; David, C.L.; Phan, A.T.; Colburn, D.E.; Rashid, A. Mylotarg (gemtuzumab ozogamicin) therapy is associated with hepatic venoocclusive disease in patients who have not received stem cell transplantation. Cancer 2001, 92, 406-413. [CrossRef]

98. Boger, D.L. Cheminform abstract: The duocarmycins: Synthetic and mechanistic studies. Acc. Chem. Res. 2002, 28, 20-29. [CrossRef]

99. Lourdes, T.; Alasdair, B.; Indrani, C.; Bilal, S.; Sanjeev, G.; Allen, Z.; Vangipuram, R.; Chetana, R.; Zemin, W.; Chin, P. Novel detection of DNA-alkylated adducts of antibody-drug conjugates with potentially unique preclinical and biomarker applications. Bioanalysis 2013, 5, 1073-1081.

100. Remillard, S.; Rebhun, L.I.; Howie, G.A.; Kupchan, S.M. Antimitotic activity of the potent tumor inhibitor maytansine. Science 1975, 189, 1002-1005. [CrossRef] [PubMed]

101. Widdison, W.C.; Wilhelm, S.D.; Cavanagh, E.E.; Whiteman, K.R.; Leece, B.A.; Yelena, K.; Goldmacher, V.S.; Hongsheng, X.; Steeves, R.M.; Lutz, R.J. Semisynthetic maytansine analogues for the targeted treatment of cancer. J. Med. Chem. 2006, 49, 4392-4408. [CrossRef] [PubMed]

102. Chari, R.V.; Martell, B.A.; Gross, J.L.; Cook, S.B.; Shah, S.A.; Blättler, W.A.; Mckenzie, S.J.; Goldmacher, V.S. Immunoconjugates containing novel maytansinoids: Promising anticancer drugs. Cancer Res. 1992, 52, 127-131. [PubMed]

103. Jeffrey, S.C.; Burke, P.J.; Lyon, R.P.; Meyer, D.W.; Sussman, D.; Anderson, M.; Hunter, J.H.; Leiske, C.I.; Miyamoto, J.B.; Nicholas, N.D. A potent anti-CD70 antibody-drug conjugate combining a dimeric pyrrolobenzodiazepine drug with site-specific conjugation technology. Bioconj. Chem. 2013, 24, 1256-1263. [CrossRef] [PubMed] 
104. Yu, S.F.; Zheng, B.; Go, M.A.; Lau, J.; Spencer, S.; Raab, H.; Soriano, R.; Jhunjhunwala, S.; Cohen, R.; Caruso, M. A novel anti-CD22 anthracycline-based antibody-drug conjugate (ADC) that overcomes resistance to auristatin based adcs. Clin. Cancer Res. 2015, 21, 3298-3306. [CrossRef] [PubMed]

105. Hallen, H.E.; Hong, L.; Scott-Craig, J.S.; Walton, J.D. Gene family encoding the major toxins of lethal amanita mushrooms. Proc. Natl. Acad. Sci. USA 2007, 104, 19097-19101. [CrossRef] [PubMed]

106. Hechler, T.; Kulke, M.; Mueller, C.; Pahl, A.; Anderl, J. Amanitin-based antibody-drug conjugates targeting the prostate-specific membrane antigen. Cancer Res. 2014, 74, 664. [CrossRef]

107. Wakelee, H.A.; Sikic, B.I. Activity of novel cytotoxic agents in lung cancer: Epothilones and topoisomerase I inhibitors. Clin. Lung Cancer 2005, 7, S6-S12. [CrossRef] [PubMed]

108. Cragg, G.M.; Pezzuto, J.M. Natural products as a vital source for the discovery of cancer chemotherapeutic and chemopreventive agents. Med. Princ. Pract. Int. J. Kuwait Univ. Health Sci. Centre 2015, 25, 41-59. [CrossRef] [PubMed]

109. Tan, L.T. Pharmaceutical agents from filamentous marine cyanobacteria. Drug Discov. Today 2013, 18, 863-871. [CrossRef] [PubMed]

110. Liua, Z.; Xua, P.; Wub, T.; Zeng, W. Microtubule-targeting anticancer agents from marine natural substance. Anti-Cancer Agents Med. Chem. 2014, 14, 1-9. [CrossRef]

111. Bai, R.L.; Pettit, G.R.; Hamel, E. Structure-activity studies with chiral isomers and with segments of the antimitotic marine peptide dolastatin 10. Biochem. Pharmacol. 1990, 40, 1859-1864. [CrossRef]

112. Maderna, A.; Leverett, C.A. Recent advances in the development of new auristatins: Structural modifications and application in antibody drug conjugates. Mol. Pharm. 2015, 12, 1798-1812. [CrossRef] [PubMed]

113. Harrigan, G.G.; Luesch, H.; Yoshida, W.Y.; Moore, R.E.; Nagle, D.G.; Paul, V.J.; Mooberry, S.L.; Corbett, T.H.; Valeriote, F.A. Symplostatin 1: A dolastatin 10 analogue from the marine cyanobacterium symploca hydnoides. J. Nat. Prod. 1998, 61, 1075-1077. [CrossRef] [PubMed]

114. Horgen, F.D.; Kazmierski, E.B.; Westenburg, H.E.; Yoshida, W.Y.; Scheuer, P.J. Malevamide D: Isolation and structure determination of an isodolastatin $\mathrm{H}$ analogue from the marine cyanobacterium Symploca hydnoides. J. Nat. Prod. 2002, 65, 487-491. [CrossRef] [PubMed]

115. Katz, J.; Janik, J.E.; Younes, A. Brentuximab vedotin (SGN-35). Clin. Cancer Res. 2011, 17, 6428-6436. [CrossRef]

116. Luesch, H.; Yoshida, W.Y.; Moore, R.E.; Paul, V.J.; Corbett, T.H. Total structure determination of apratoxin a, a potent novel cytotoxin from the marine cyanobacterium lyngbya majuscula. J. Am. Chem. Soc. 2001, 123, 5418-5423. [CrossRef] [PubMed]

117. Luesch, H.; Yoshida, W.Y.; Moore, R.E.; Paul, V.J. New apratoxins of marine cyanobacterial origin from guam and palau. Bioorg. Med. Chem. 2002, 10, 1973-1978. [CrossRef]

118. Cooper, E.L.; Yao, D. Diving for drugs: Tunicate anticancer compounds. Drug Discov. Today 2012, 17, $636-648$. [CrossRef] [PubMed]

119. D'Incalci, M.; Galmarini, C.M. A review of trabectedin (ET-743): A unique mechanism of action. Mol. Cancer Ther. 2010, 9, 2157-2163. [CrossRef] [PubMed]

120. D'Incalci, M.; Badri, N.; Galmarini, C.M.; Allavena, P. Trabectedin, a drug acting on both cancer cells and the tumour microenvironment. Br. J. Cancer 2014, 111, 646-650. [CrossRef] [PubMed]

121. Galmarini, C.M.; Maurizio, D.I.; Paola, A. Trabectedin and plitidepsin: Drugs from the sea that strike the tumor microenvironment. Mar. Drugs 2014, 12, 719-733. [CrossRef] [PubMed]

122. Mayer, A.M.S.; Glaser, K.B.; Cuevas, C.; Jacobs, R.S.; Kem, W.; Little, R.D.; Mcintosh, J.M.; Newman, D.J.; Potts, B.C.; Shuster, D.E. The odyssey of marine pharmaceuticals: A current pipeline perspective. Trends Pharmacol. Sci. 2010, 31, 255-265. [CrossRef] [PubMed]

123. Schöffski, P.; Guillem, V.; Garcia, M.; Rivera, F.; Tabernero, J.; Cullell, M.; Lopezmartin, J.A.; Pollard, P.; Dumez, H.; del Muro, X.G. Phase II randomized study of plitidepsin (aplidin), alone or in association with 1-carnitine, in patients with unresectable advanced renal cell carcinoma. Mar. Drugs 2009, 7, 57-70. [CrossRef] [PubMed]

124. Couture, F.; Lorigan, P.; Lüthi, F.; Small, D. Phase II study of weekly plitidepsin as second-line therapy for small cell lung cancer. Lung Cancer 2008, 64, 60-65.

125. Monaco, R. Novel natural product discovery from marine sponges and their obligate symbiotic organisms. Biorxiv 2014. [CrossRef]

126. Menis, J.; Twelves, C. Eribulin (halaven): A new, effective treatment for women with heavily pretreated metastatic breast cancer. Breast Cancer Targets Ther. 2011, 3, 101-111. [CrossRef] [PubMed] 
127. Preston, J.N.; Trivedi, M.V. Eribulin: A novel cytotoxic chemotherapy agent. Ann. Pharmacother. 2012, 46, 802-811. [CrossRef] [PubMed]

128. Shetty, N.; Gupta, S. Eribulin drug review. South Asian J. Cancer 2014, 3, 57-59. [PubMed]

129. Chen, R.; Liu, H.; Chen, C. Asymmetric total synthesis of (-)-jorunnamycins A and C and (-)-jorumycin from 1-tyrosine. J. Nat. Prod. 2013, 76, 1789-1795. [CrossRef]

130. Capdevila, J.; Clive, S.; Casado, E.; Michie, C.; Piera, A.; Sicart, E.; Carreras, M.J.; Coronado, C.; Kahatt, C.; Matos-Pita, A.S. A phase i pharmacokinetic study of PM00104 (Zalypsis) administered as a 24-h intravenous infusion every 3 weeks in patients with advanced solid tumors. Cancer Chemother. Pharmacol. 2013, 71, 1247-1254. [CrossRef] [PubMed]

131. Jones, R.L.; Ferrari, S.; Blay, J.Y.; Navid, F.; Lardelli, P.; Alfaro, V.; Siguero, M.; Soman, N.; Chawla, S.P. A phase II multicenter, open-label, clinical and pharmokinetic trial of PM00104 in patients with advanced ewing family of tumors. Investig. New Drugs 2014, 32, 171-177. [CrossRef] [PubMed]

132. Michela, R.; Roberta, F.; Monique, Z.; Ezia, B.; Luca, P.; Galmarini, C.M.; García-Fernández, L.F.; Carmen, C.; Paola, A.; Eugenio, E. Comparison of in vitro and in vivo biological effects of trabectedin, lurbinectedin (PM01183) and Zalypsis ${ }^{\circledR}$ (PM00104). Langmuir 2013, 12, 3157-3161.

133. Newman, D.J.; Cragg, G.M. Marine-sourced anti-cancer and cancer pain control agents in clinical and late preclinical development. Mar Drugs 2014, 12, 255-278. [CrossRef] [PubMed]

134. Tan, L.T. Filamentous tropical marine cyanobacteria: A rich source of natural products for anticancer drug discovery. J. Appl. Phycol. 2010, 22, 659-676. [CrossRef]

(C) 2017 by the authors; licensee MDPI, Basel, Switzerland. This article is an open access article distributed under the terms and conditions of the Creative Commons Attribution (CC-BY) license (http:/ / creativecommons.org/licenses/by/4.0/). 